\title{
Widespread Phytophthora infestations in European nurseries put forest, semi-natural and horticultural ecosystems at high risk of Phytophthora diseases
}

T. Jung ${ }^{1,2,40}$, L. Orlikowski ${ }^{3}$, B. Henricot ${ }^{4}$, P. Abad-Campos ${ }^{5}$, A. G. Aday ${ }^{6}$, O. Aguín Casal ${ }^{7}$, J. Bakonyi ${ }^{8}$, S. O. Cacciola ${ }^{9}$, T. Cech $^{10}$, D. Chavarriaga ${ }^{11}$, T. Corcobado ${ }^{12}$, A. Cravador ${ }^{1}$, T. Decourcelle ${ }^{13}$, G. Denton ${ }^{4}$, S. Diamandis ${ }^{14}$,

H. T. Doğmuş-Lehtijärvi ${ }^{7}$, A. Franceschini ${ }^{15}$, B. Ginetti ${ }^{16}$, S. Green ${ }^{17}$, M. Glavendekić ${ }^{18}$, J. Hantula ${ }^{19}$, G. Hartmann ${ }^{20}$, M. Herrero ${ }^{21}$, D. Ivic ${ }^{22}$, M. Horta Jung ${ }^{1}$, A. Lilja ${ }^{19}$, N. Keca ${ }^{18}$, V. Kramarets ${ }^{23}$, A. Lyubenova ${ }^{24}$, H. Machado ${ }^{25}$, G. Magnano di San Lio $^{26}$, P. J. Mansilla Vázquez ${ }^{7}$, B. Marçais ${ }^{27}$, I. Matsiakh ${ }^{23}$, I. Milenkovic ${ }^{18}$, S. Moricca ${ }^{16}$, Z. Á. Nagy ${ }^{8}$, J. Nechwatal ${ }^{28}$, C. Olsson $^{29}$, T. Oszako ${ }^{30}$, A. Pane ${ }^{9}$, E. J. Paplomatas ${ }^{31}$, C. Pintos Varela ${ }^{7}$, S. Prospero ${ }^{32}$, C. Rial Martínez ${ }^{7}$, D. Rigling ${ }^{32}$, C. Robin ${ }^{13}$, A. Rytkönen ${ }^{19}$, M. E. Sánchez ${ }^{33}$, A. V. Sanz Ros ${ }^{34}$, B. Scanu ${ }^{15}$, A. Schlenzig ${ }^{35}$, J. Schumacher ${ }^{36}$, S. Slavov ${ }^{24}$, A. Solla ${ }^{12}$, E. Sousa ${ }^{25}$, J. Stenlid ${ }^{29}$, V. Talgø ${ }^{21}$, Z. Tomic ${ }^{22}$, P. Tsopelas ${ }^{37}$, A. Vannini $^{38}$, A. M. Vettraino ${ }^{38}$, M. Wenneker $^{39}$, S. Woodward ${ }^{11}$ and A. Peréz-Sierra ${ }^{17}$

${ }^{1}$ Center for Mediterranean Bioresources and Food (MeditBio), Laboratory of Molecular Biotechnology and Phytopathology, University of Algarve, Campus de Gambelas, 8005-139 Faro, Portugal; ${ }^{2}$ Phytophthora Research and Consultancy, Nußdorf, Germany; ${ }^{3}$ Institute of Horticulture, Skierniewice, Poland; ${ }^{4}$ Royal Horticultural Society, Woking, Surrey, UK; ${ }^{5}$ Grupo de Investigación en Hongos Fitopatógenos, Instituto Agroforestal Mediterráneo, Universidad Politécnica de Valencia, Valencia, Spain; ${ }^{6}$ Faculty of Forestry, Süleyman Demirel University, Isparta, Turkey; ${ }^{7}$ EXCMA, Diputación Provincial de Pontevedra, Servicio Agrario, Estación Fitopatológia “do Areeiro", Pontevedera, Spain; ${ }^{8}$ Plant Protection Institute, Hungarian Academy of Sciences, Budapest, Hungary; ${ }^{9}$ Department of Agri-Food and Environmental Systems Management, Plant Pathology Section, University of Catania, Catania, Italy; ${ }^{10}$ Federal Research and Training Centre for Forests, Natural Hazards and Landscape (BFW), Vienna, Austria; ${ }^{11}$ Institute of Biological and Environmental Sciences, University of Aberdeen, Aberdeen, UK; ${ }^{12}$ Ingeniería Técnica Forestal, Universidad de Extremadura, Plasencia, Spain; ${ }^{13}$ INRA, UMR BioGeCo, Cestas Cedex, France; ${ }^{14}$ NAGREF-Forest Research Institute, Vassilika-Thessaloniki, Greece; ${ }^{15}$ Dipartimento di Agraria, Sezione di Patologia vegetale ed Entomologia (SPaVE), Università degli Studi di Sassari, Sassari, Italy; ${ }^{16}$ Department of Agri-food Production and Environmental Sciences, Plant Pathology and Entomology Division, University of Florence, Florence, Italy; ${ }^{17}$ Forest Research, Alice Holt Lodge, Farnham, Surrey GU10 4LH, UK; ${ }^{18}$ Faculty of Forestry, University of Belgrade, Belgrade, Serbia; ${ }^{19}$ Finnish Forest Research Institute, Vantaa Research Centre, Vantaa, Finland; ${ }^{20}$ Lower Saxony Forest Research Station, Göttingen, Germany; ${ }^{21}$ Norwegian Institute for Agricultural and Environmental Research (Bioforsk), Plant Health and Plant

Protection Division, Ås, Norway; ${ }^{22}$ Institute for Plant Protection, Croatian Centre for Agriculture, Food and Rural Affairs, Zagreb, Croatia; ${ }^{23}$ Forestry Department, National Forestry University of Ukraine, Lviv, Ukraine; ${ }^{24}$ Agrobioinstitute, Centre of Excellence in Plant Biotechnology, Sofia, Bulgaria; ${ }^{25}$ Instituto Nacional de Recursos Biológicos, Unidade de Silvicultura e Produtos Florestais, Oeira, Portugal; ${ }^{26}$ Dipartimento di Agraria, University Mediterranea of Reggio Calabria, 89122 Reggio Calabria, Italy; ${ }^{27}$ INRA, Nancy Universite', UMR 1136 Interactions Arbres/ Microorganismes, Champenoux, France; ${ }^{28}$ Bavarian State Institute of Agriculture (LfL), Freising, Germany; ${ }^{29}$ Department of Forest Mycology and Pathology, Swedish University of Agricultural Sciences, Uppsala, Sweden; ${ }^{30}$ Department of Forest Phytopathology, Forest Research Institute, Raszyn, Poland; ${ }^{31}$ Laboratory of Plant Pathology, Agricultural University of Athens, Athens, Greece; ${ }^{32}$ Swiss Federal Institute for Forest, Snow and Landscape Research WSL, Birmensdorf, Switzerland; ${ }^{33}$ Departamento Agronomía, ETSIAM, Universidad de Córdoba, Apdo, Córdoba, Spain; ${ }^{34}$ Centro de Sanidad Forestal de Calabazanos, 34190, Palencia, Spain; ${ }^{35}$ Scottish Government-SASA, Plant Health, Edinburgh,

UK; ${ }^{36}$ Department of Forest Protection, Forest Research Institute Baden-Wuerttemberg, Freiburg, Germany; ${ }^{37}$ NAGREF-Institute of

Mediterranean Forest Ecosystems, Terma Alkmanos, Athens, Greece; ${ }^{38}$ Department for Innovation in Biological, Agro-Food and Forest Systems, University of Tuscia, Viterbo, Italy; ${ }^{39}$ Wageningen UR/Applied Plant Research, Sector Flower bulbs, Tree nursery \& Fruit, Zetten, the Netherlands; ${ }^{40}$ E-mail: trjung@ualg.pt (for correspondence)

\section{Summary}

An analysis of incidence of Phytophthora spp. in 732 European nurseries producing forest transplants, larger specimen trees, landscape plants and ornamentals, plus 2525 areas in which trees and shrubs were planted, is presented based on work conducted by 38 research groups in 23 European countries between 1972 and 2013. Forty-nine Phytophthora taxa were recorded in 670 nurseries (91.5\%); within these nurseries, 1614 of 1992 nursery stands (81.0\%) were infested, although most affected plants appeared healthy. In forest and landscape plantings, 56 Phytophthora taxa were recovered from 1667 of 2525 tested sites (66.0\%). Affected plants frequently showed symptoms such as crown thinning, chlorosis and dieback caused by extensive fine root losses and/or collar rot. Many well-known highly damaging host-Phytophthora combinations were frequently detected but 297 and 407 new Phytophthora-host associations were also observed in nurseries and plantings, respectively. On average, 1.3 Phytophthora species/taxa per infested nursery stand and planting site were isolated. At least 47 of the 68 Phytophthora species/taxa detected in nurseries and plantings were exotic species several of which are considered well established in both nurseries and plantings in Europe. Seven known Phytophthora species/taxa were found for the first

[Correction added on 6 January 2016 after first online publication: The authors name S. Green and A. V. Sanz Ros have been included along with the affiliations in the authors list.].

Received: 6.4.2015; accepted: 4.9.2015; editor: M.-L. Deprez-Loustau 
time in Europe, while 10 taxa had not been previously recorded from nurseries or plantings; in addition, 5 taxa were first detections on woody plant species. Seven Phytophthora taxa were previously unknown to science. The reasons for these failures of plant biosecurity in Europe, implications for forest and semi-natural ecosystems and possible ways to improve biosecurity are discussed.

\section{Introduction}

Phytophthora is a genus of major importance within the Oomycota, kingdom Straminipila, currently comprising approximately 150 described species and informally designated taxa, most being primary plant pathogens which are responsible for over $66 \%$ of all fine root diseases and more than $90 \%$ of all collar rots of woody plant species (Tsao 1990; Brasier 2009; Jung et al. 2011; Kroon et al. 2012). Phytophthora species can be highly invasive and, after introduction to a new continent, may affect growth, vitality and longevity of trees, sometimes destabilizing whole ecosystems. Due to a lack of co-evolution between introduced Phytophthora spp. and endemic plants, hosts in the invaded region are usually more susceptible than host plants in the native range. Some of the most destructive and well-documented epidemics of trees and forests are caused by alien Phytophthora species; Jarrah dieback in Western Australia and littleleaf disease of pines in the south-eastern USA, New Zealand and the Dominican Republic by P. cinnamomi (Oak and Tainter 1988; Shearer and Tippett 1989; Jung and Dobler 2002); mortality of Chamaecyparis lawsoniana in Oregon by P. lateralis (Hansen et al. 2000; Jules et al. 2002) and Austrocedrus chilensis in Patagonia by P. austrocedrae (Greslebin et al. 2007); ink disease of Castanea species in Europe and the USA by P. cinnamomi and P. cambivora (Vettraino et al. 2001, 2005; Jung et al. 2013a); and the extensive mortality of Quercus spp. and Notholithocarpus densiflorus in California and Larix kaempferi in the UK and Ireland by P. ramorum (Rizzo et al. 2002; Brasier and Webber 2010; Grünwald et al. 2012).

In Europe, large-scale surveys for soilborne Phytophthora species in over 4000 forests and semi-natural ecosystems have been undertaken since the mid-1990s stimulated by several devastating declines and diebacks of major forest and riparian tree species (Brasier et al. 1993; Jung and Blaschke 1996, 2004; Jung et al. 1996, 2000, 2013a; Gallego et al. 1999; Hansen and Delatour 1999; Vettraino et al. 2001, 2002, 2005; Streito et al. 2002; Balci and Halmschlager 2003a,b; Gibbs et al. 2003; Jung 2009; Orlikowski et al. 2011). In Mediterranean and temperate regions of Europe, 20 Phytophthora species and taxa, including the introduced wide host range pathogens $P$. cambivora, $P$. cinnamomi and P. plurivora, and the oak-specific $P$. quercina, have regularly been found to be associated with both a chronic decline and a rapid mortality of Quercus species characterized by progressive destruction of fine root systems that predispose affected oaks to droughts and secondary pathogens and pests (Brasier et al. 1993; Jung et al. 1996, 2000, 2013a; Robin et al. 1998; Balci and Halmschlager 2003a, b; Vettraino et al. 2002; Jönsson et al. 2005; Pérez-Sierra et al. 2013). Since the early 1990s, a root and collar rot epidemic caused by the interspecific hybrids $P . \times$ alni (PAA) and P. $\times$ multiformis (PAM) and P. uniformis (PAU) has caused high levels of mortality of Alnus spp. in riparian and forest stands in most parts of Europe (Streito et al. 2002; Gibbs et al. 2003; Brasier et al. 2004; Jung and Blaschke 2004; Jung et al. 2013a; Husson et al. 2015). Also there has been a recent upsurge in ink disease of Castanea sativa in Southern and Eastern Europe and the UK (Vettraino et al. 2001, 2005; Jung et al. 2013a). The most recent of these threats which is causing great concern to foresters, arboriculturists and conservationists across Europe is the widespread decline and dieback of European beech (Fagus sylvatica), an important tree species in Western and Central Europe and in mountain areas of Eastern and Southern Europe, forming almost pure stands on many sites. Since the late 1990s, an increasing number of beech stands in Austria, Belgium, Germany, Italy, Poland, Romania, Sweden, the Czech Republic and the UK are showing crown transparency and dieback, small-sized and often yellowish foliage and eventual mortality. Phytophthora cambivora, $P$. cactorum and P. plurivora were consistently associated with the disease causing extensive fine root losses, root and collar rot, and aerial bleeding cankers on stems (Jung et al. 2005, 2013a; Brown and Brasier 2007; Jung 2009). Another 11 Phytophthora species showed scattered distribution in beech stands sometimes causing serious decline and mortality on a local or regional scale such as P. kernoviae and P. ramorum in the UK and P. pseudosyringae in Germany and Italy (Brown and Brasier 2007; Jung 2009; Jung et al. 2013a).

Both soilborne and airborne Phytophthora species can survive unsuitable conditions with resting structures in soil, infected roots and organic debris; hence, movement of soil particles and roots, particularly with plants for planting, is generally considered the major pathway for Phytophthora species (Shearer and Tippett 1989; Erwin and Ribeiro 1996; Brasier 2008; Jung et al. 2013a). Phytophthora infestations of nursery stock are well documented in Australia and the USA (Hardy and Sivasithamparam 1988; MacDonald et al. 1994; Davison et al. 2006; Schwingle et al. 2007; Yakabe et al. 2009; Bienapfl and Balci 2014; Parke et al. 2014), and initial work suggests a similar situation in Europe (Themann et al. 2002; Moralejo et al. 2009; Pérez-Sierra and Jung 2013). Most work has focused on ornamental nurseries and the economic losses damping-off and root and collar rots cause to the nurseries and ornamental industry in general. However, recent epidemics and small-scale surveys of alder, birch, beech and fir fields in Finland, Germany and Poland (Lilja et al. 1996; Orlikowski et al. 2004; Jung 2009) have drawn attention to the role of infested nursery stock as major pathway of Phytophthora diseases into forests and semi-natural ecosystems within and between continents.

This paper reports on a series of small- and large-scale surveys for Phytophthora infestations of (i) forest nurseries, nurseries producing large trees for amenity and landscape plantings, horticultural and ornamental nurseries and (ii) forest, riparian, amenity, landscape and ornamental plantings and horticultural plantations in 23 European countries conducted by 38 research groups between 1972 and 2013, with most surveys conducted after 2000. The implications of the results for forestry, horticulture, conservation and plant biosecurity in Europe and possible solutions are discussed. 


\section{Materials and methods}

\subsection{Nurseries and plantings sampled}

Anonymity was a precondition for all participating nursery owners and many owners of plantings; therefore, only national codes rather than precise locations and names are stated. Although most nurseries were selected randomly, some analyses were carried out in response to requests from the owners.

Between 1972 and 2013, 304 woody and herbaceous plant species in 1992 nursery stands, 629 fields with plants in the ground (hereafter referred to as nursery fields) and 1363 container stands (including plants in trays and in larger pots) were surveyed for Phytophthora infestations. Types of production for the nurseries in the 18 European states are detailed in Table 1. Of the 732 nurseries examined, 261 were wholesale and 424 were retail outlets, and 47 nurseries were publically owned by, for example, state forestry administrations.

Table 2 displays the types of plants grown in the nursery fields and container stands.

To study the pathway from nurseries into natural, semi-natural and horticultural ecosystems, 2525 forest, amenity, landscape, riparian and ornamental plantings and horticultural plantations with 478 woody and herbaceous plant species and taxa in 20 European countries were examined for Phytophthora-related disease symptoms and Phytophthora infestations (Table 1). Twenty-seven plantings were mixed amenity/ornamental plantings. Most forest and riparian plantings and approximately half of the amenity and landscape plantings were selected randomly. The remaining amenity and landscape plantings and the majority of the ornamental and/or horticultural plantings were examined following reports of damage.

Further analysis of the nursery to forest ecosystems pathway was possible through searches of the database of the French Département de la Santé des Forêts (DSF). These data enabled determination of the relationship between the planting of nursery seedlings and presence of ink disease, induced by P. cinnamomi, on oaks. In France, ink disease is currently restricted to the Aquitaine and Midi-Pyrénées regions (Marçais et al. 2004). All reports of Quercus robur, Quercus petraea and Quercus pubescens with information on the establishment type of the stand were selected, and reports of ink disease in planted and naturally regenerated stands, respectively, were compared using logistic regression in R software.

\subsection{Sampling strategies}

Sampling strategies varied over time and between research groups performing the surveys reported here. Generally, however, in nurseries, between 10 and 40 plants of 1-3 years old per field or container stand were harvested together with adhering soil. If present, seedlings with symptoms such as wilting, dieback, chlorosis and root and collar rot were preferentially sampled.

In nurseries producing advanced stock, plants were between 1 and 20 years old, and either containerized or rootpruned, balled and wrapped in burlap. With 1- to 3-year-old plants, sampling was carried out as described above. For older trees, 3-10 trees per species and field were randomly selected, 2-3 soil samples taken from the root ball of each tree and the soils combined to a bulked sample of approximately $1 \mathrm{l}$ per tree.

In forest, amenity and landscape plantings, 3-10 symptomatic trees per species and planting were selected and soil samples taken as described for advanced stock.

When necrotic root or collar lesions were present, bark samples including the cambium were taken from the lesions and transported to the laboratory for further analyses, following published methods (Jung and Blaschke 2004). Symptomatic shoots and foliage were also sampled in ornamental nurseries or plantings by cutting and wrapping in moist tissue for transport to the laboratory in cool boxes.

\subsection{Detection and identification methods}

Phytophthora spp. were isolated from samples mainly using baiting methods, with leaves, green apples or hemp seed as baits over flooded soil or washed root systems (Erwin and Ribeiro 1996; Jung et al. 1996; Themann et al. 2002; Jung 2009). An alternative method of placing moistened soil in green apples (cv. Granny Smith) was sometimes used (Erwin and Ribeiro 1996; Jung et al. 1996). Different baits and media used in subsequent isolations in individual countries are listed in Table 1. Necrotic bark samples were washed repeatedly in distilled water over 1-3 days to remove excess polyphenols before either plating parts of the lesions on selective media or placing the bark in distilled water and baiting with oak and beech leaflets (Jung 2009).

Colonies growing from baits and bark pieces were transferred to V8-juice agar (V8A; Erwin and Ribeiro 1996) for initial confirmation as Phytophthora species. Identifications were made by comparing colony growth patterns, cardinal temperatures of growth and microscopic morphological characteristics with those of species descriptions in the literature (e.g. Erwin and Ribeiro 1996; Jung et al. 1999, 2002, 2003, 2011; Werres et al. 2001; Brasier et al. 2003a,b; Brasier et al. 2004, 2005; Greslebin et al. 2007; Balci et al. 2008; Hansen et al. 2009; Jung and Burgess 2009; Scott et al. 2009; Hong et al. 2011; Nechwatal et al. 2013; Ginetti et al. 2014; Henricot et al. 2014; Scanu et al. 2014a). Self-sterile isolates were crossed with tester strains of known mating types from CBS (Centraalbureau voor Schimmelcultures, Utrecht, the Netherlands) to stimulate production of oogonia. Sporangia were observed on 15-mm squares cut from the growing edge of a 5- to 7-dayold culture grown on V8A at $20^{\circ} \mathrm{C}$ in the dark, and flooded for $24-36 \mathrm{~h}$ in $90-\mathrm{mm}$ Petri dishes with non-sterile soil extract or pond water (Jung et al. 1996). 


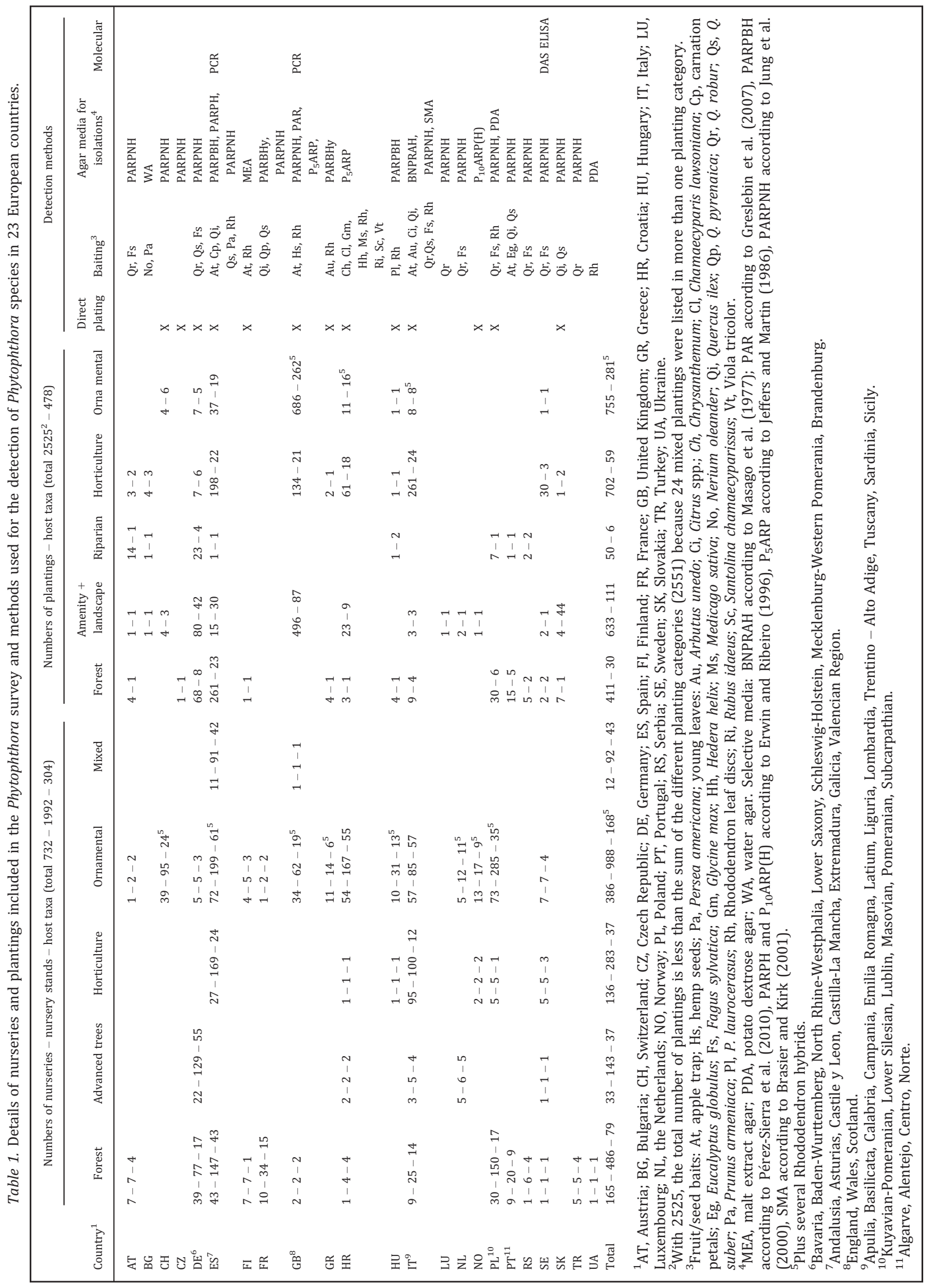




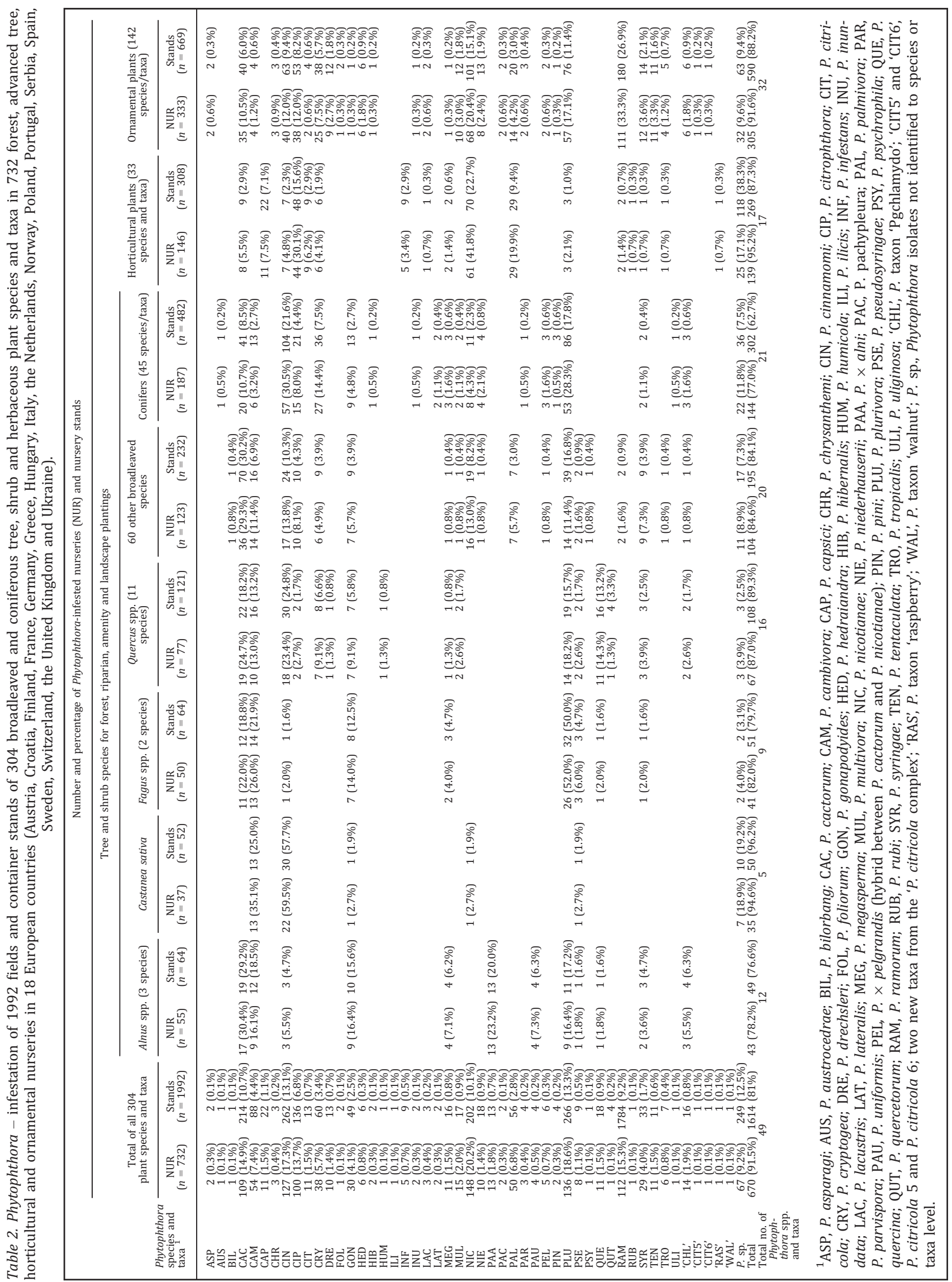


Once the technologies and databases became available, confirmation of identifications was made using polymerase chain reaction (PCR) to amplify ITS-rDNA, followed by sequencing and comparison against sequences in databases such as GenBank and PhytophthoraDB (e.g. Cooke et al. 2000; Cullen et al. 2001).

\section{Results}

\subsection{Nursery surveys}

\subsubsection{Diversity and distribution of Phytophthora species and infestation rates in nurseries}

In total, 49 Phytophthora taxa including 42 Phytophthora species and subspecies, four informally designated Phytophthora taxa and three previously unknown Phytophthora taxa were isolated from 81\% of the 1992 tested fields and container stands in $91.5 \%$ of 732 nurseries surveyed (Table 2; Fig. 1). In the 101 infested nurseries with at least five tested stands, 3.6 Phytophthora taxa per nursery were detected. With 88.3-97.1\%, mean infestation levels of the different types of nurseries at the nursery level were comparable. At the level of the individual nursery stand, however, mean infestation levels in the different nursery types ranged from 68.5 to $77.6 \%$ in mixed and ornamental nurseries, respectively, and $81.5 \%$ in forest nurseries to $90.5 \%$ and $92.3 \%$ in horticultural and advanced tree nurseries, respectively. The frequency of Phytophthora infestation was almost identical in both field and container stands, at 80.1 and 81.4\%, respectively. Marketing category had a weak influence on Phytophthora infestation level. Infestation in the 261 tested wholesale nurseries (95.8\% of nurseries and $88.4 \%$ of nursery stands) was higher than that in the 424 retail nurseries (88.4\% and $77.2 \%)$ and the 47 administration nurseries (95.7\% and $78.1 \%$ ).

Mean infestation levels in nursery stands varied considerably with tree/crop species. Amongst trees grown for forest, riparian, amenity and landscape plantings with over 10 tested nursery stands, infestations of approximately 10-20\% occurred in Picea omorika, Picea glauca and Juniperus spp., compared with $100 \%$ in both Quercus ilex and Quercus suber, 96.2\% in Castanea sativa, 93.8\% in Pinus radiata and 90.2\% in Chamaecyparis lawsoniana (Tables S2, S4, S6). For horticultural plant species with over 10 tested nursery stands, the extremes were represented by Lactuca sativa and Vitis vinifera (38.5\% and 58.3\%, respectively) and seven Citrus species/hybrids and Olea europea (all 100\%) (Table S7). Amongst ornamental plant species with over five tested nursery stands, several species were all infested, whereas the lowest infestation rates were for Vinca minor (42.9\%) and Forsythia $\times$ intermedia (50\%) (Table S8). Highest diversity in Phytophthora species was found in nursery stands of Alnus glutinosa and C. lawsoniana (each 13 Phytophthora taxa), Q. robur and Buxus sempervirens (each 12 Phytophthora taxa), Taxus baccata (11), Viburnum tinus (10), Q. ilex (9) and Fagus sylvatica (8).

In the 1614 infested nursery stands, 2076 Phytophthora taxon-nursery stand associations were found with 1827 identified to Phytophthora species level (Fig. 1). Multiple isolates of a Phytophthora taxon from the same nursery stand were considered as one record. The most commonly sampled Phytophthora species were P. plurivora, P. cinnamomi, P. cactorum, $P$. nicotianae, $P$. ramorum and $P$. citrophthora, all alien invasive species in Europe (Fig. 1). First records for Europe included P. chrysanthemi, P. foliorum and P. quercetorum, whereas P. asparagi, P. bilorbang, P. humicola, P. ilicis, P. inundata, P. uliginosa and $P$. taxon 'Walnut' are first records in European nurseries.

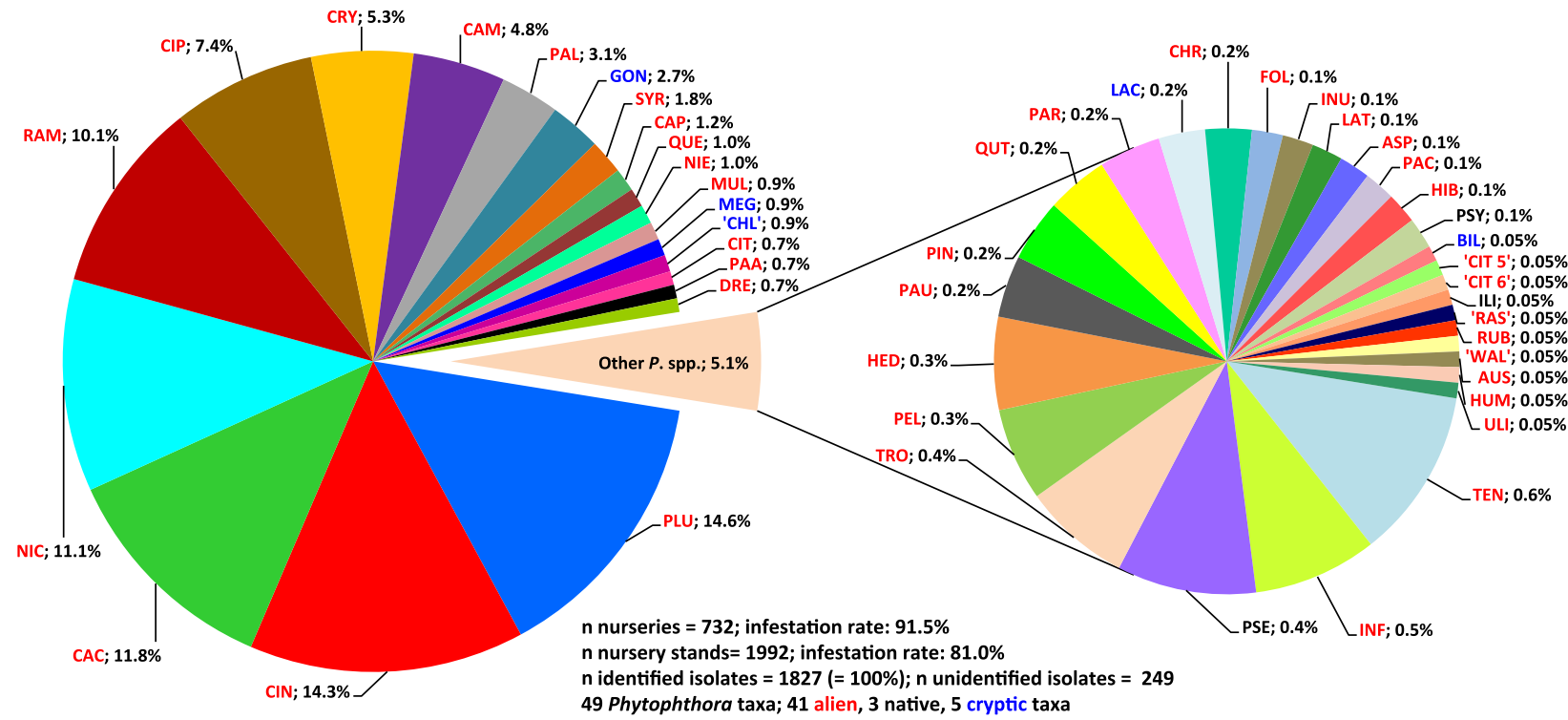

Fig. 1. Diversity and frequency of alien, native and cryptic Phytophthora taxa in 1992 fields and container stands of 732 forest, advanced tree, horticultural and ornamental nurseries in 18 European countries. Multiple isolates of a Phytophthora taxon from the same nursery stand were considered as one record. Abbreviated Phytophthora names are explained in footnote 1 of Table 2. 
Nursery surveys confirmed known or assumed host specificities or preferences of several Phytophthora taxa including, amongst others, P. $\times$ alni (PAA) and P. uniformis (PAU) and Alnus spp., P. foliorum and Azalea sp., P. ilicis and Ilex aquifolium, and P. quercetorum and P. quercina and Quercus species. In one German nursery, however, P. quercina was isolated from the rhizosphere of 2-year-old F. sylvatica seedlings growing in a former Quercus field. In contrast, for many known wide host range species, between 18 and 81 host associations were recorded (Tables S1-S8).

Thirteen of the 49 Phytophthora spp. occurred in all three major climatic regions, although frequency and composition of the populations differed considerably (Fig. 2). Of the 304 surveyed plant species, 21 were present in all three climatic regions, whereas 14 and 12 species were shared between the Atlantic region and the Mediterranean and subcontinental to continental regions, respectively; the latter two regions shared 10 plant species. In 187 nurseries tested in Atlantic regions,
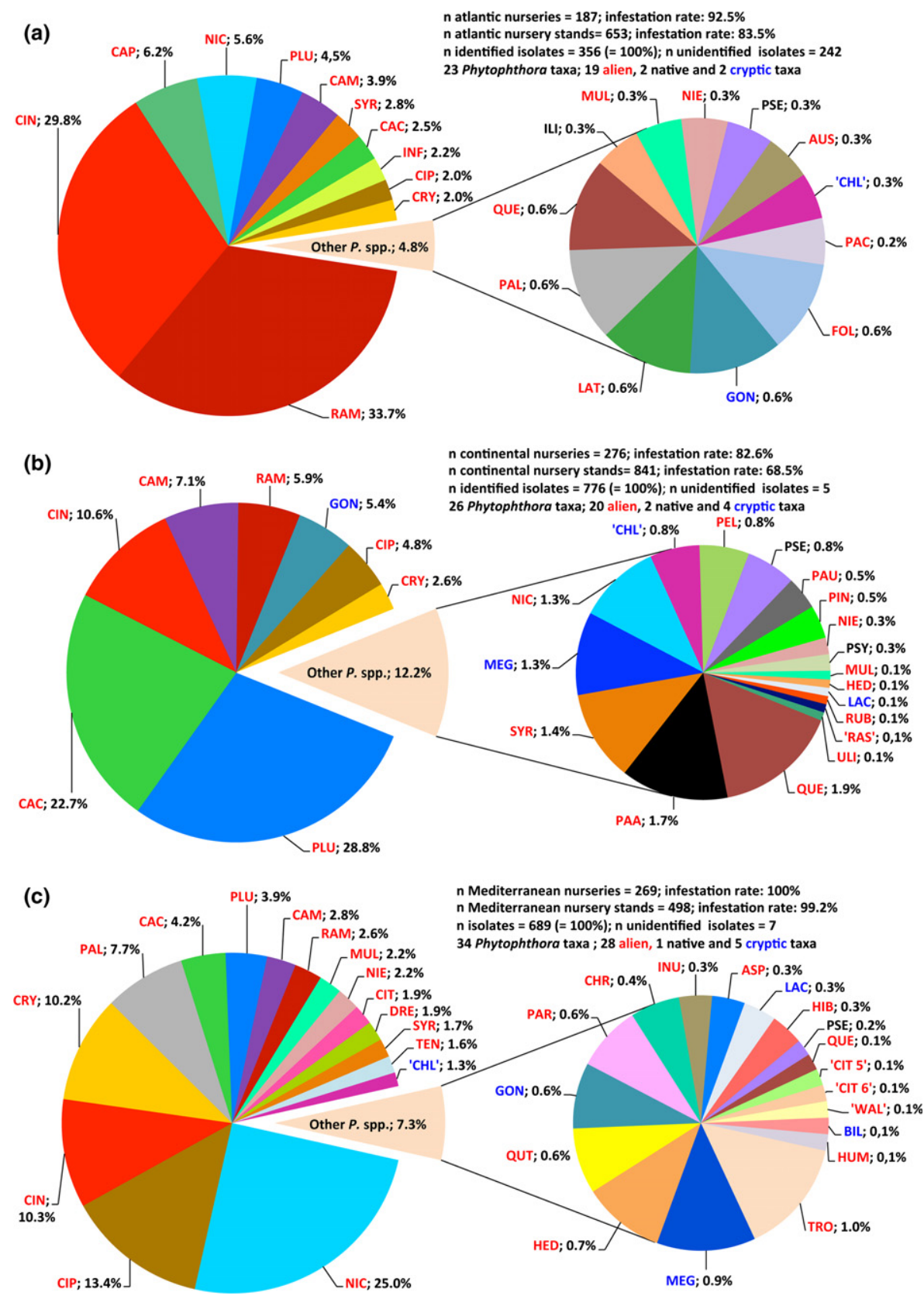

Fig. 2. Diversity and frequency of alien, native and cryptic Phytophthora taxa in fields and container stands of forest, advanced tree, horticultural and ornamental nurseries in different climatic regions of Europe a: 653 fields and container stands of 187 nurseries in Atlantic regions (ES, FR, GB, NL); b: 841 fields and container stands of 276 forest, advanced tree, horticultural and ornamental nurseries in subcontinental to continental regions of Europe (AT, CH, DE, FI, HU, NO, PL, RS, SE, UA); c: 498 fields and container stands of 269 nurseries in Mediterranean regions of Europe (ES, FR, GR, IT, HR, PT, TR). Multiple isolates of a Phytophthora taxon from the same nursery stand were considered as one record. Abbreviated Phytophthora names are explained in footnote 1 of Table 2. 
23 Phytophthora taxa were detected in $83.5 \%$ of the 653 sampled stands (Fig. 2a). In humid and mild climates, Phytophthora species with a predominantly aerial lifestyle and frost-sensitive Phytophthora species with subtropical to tropical origins accounted for $41 \%$ and $36 \%$ of the Phytophthora-nursery stand associations, respectively. The most common species were P. ramorum and P. cinnamomi (Fig. 2a). In subcontinental to continental regions, 26 Phytophthora taxa were recovered from 576 of the 841 nursery stands surveyed in 228 of the 276 nurseries (Fig. 2b). Aerial and frost-sensitive Phytophthora species represented $7.5 \%$ and $12.2 \%$ of Phytophthora-nursery stand associations, respectively. In contrast, species adapted to survive severe winter frost represented 82.1\% of Phytophthora-nursery stand associations. Phytophthora plurivora and P. cactorum were the most common species followed by P. cinnamomi. Thirty-four Phytophthora taxa were isolated from 494 of 498 nursery stands tested in 269 Mediterranean nurseries (Fig. 2c). The proportion of frostsensitive thermophilous species was $46.2 \%$, whereas predominantly aerial Phytophthora species represented $11.6 \%$ of Phytophthora-nursery stand associations. Phytophthora nicotianae was the most common species followed by P. citrophthora, P. cinnamomi and P. cryptogea. Thirteen Phytophthora taxa were exclusive to Mediterranean nurseries.

\subsubsection{Alnus stands}

Eleven Phytophthora species, plus P. taxon 'PgChlamydo', were isolated from $76.6 \%$ of the 64 fields and container stands of Alnus spp. in $78.2 \%$ of the 55 nurseries assessed in seven countries (Fig. 3a; Tables 2, S1). PAA and PAU were detected in 20\% and $6.3 \%$ of all Alnus fields, respectively. Infestation rates were highest in Germany, where eight nurseries hosted three or more Phytophthora taxa per Alnus field. In a Bavarian nursery, a single field was infested with eight different Phytophthora taxa (PAA, PAU, P. cambivora, P. gonapodyides, P. megasperma, P. plurivora, P. syringae and P. taxon 'PgChlamydo'), and five Phytophthora species were recovered from the rhizosphere of a single A. glutinosa plant. PAA and PAU were only present in Alnus fields established with nursery stock bought in from other nurseries and/or when surface water had been used for irrigation (Table S1).

\subsubsection{Castanea sativa stands}

Of 52 nursery stands of C. sativa tested in 37 nurseries in seven countries, 96.2\% were Phytophthora-infested. Phytophthora cinnamomi and P. cambivora were the most common species (Fig. 3c; Tables 2 and S2).

\subsubsection{Fagus stands}

Nine Phytophthora species were isolated from $79.7 \%$ of 64 stands of F. sylvatica and F. orientalis in $82 \%$ of 50 nurseries in six countries. Phytophthora cactorum, P. cambivora, P. gonapodyides and P. plurivora were recovered from 18.8, $21.9,12.5$ and $50 \%$ of the beech fields, respectively (Fig. 3d; Tables 2 and S3). At least one of these four pathogens was present in over $75 \%$ of the 64 Fagus stands tested (Table S3).

\subsubsection{Quercus stands}

Almost $90 \%$ of 121 fields and container stands of 11 oak species surveyed in $87 \%$ of the 77 nurseries tested in eight countries were infested with 16 Phytophthora species in total (Fig. 3b; Tables 2 and S4). Over all countries, P. cinnamomi, P. cactorum, P. plurivora, P. cambivora and P. quercina were most frequently isolated (Table 2). However, diversity differed considerably between nurseries in Atlantic and subcontinental to continental, and in Mediterranean regions. In Germany, the Netherlands, Poland, Serbia, the UK and temperate regions of France and Spain, P. cactorum, P. plurivora and P. quercina were most common, whereas in Italy, Portugal and Mediterranean regions of France and Spain, P. cinnamomi, P. cambivora and P. cryptogea prevailed. Phytophthora quercetorum was isolated in one Portuguese forest nursery from four Quercus spp. in different container stands (Table S4), a first record in Europe.

Overall, 65.3\% of the 121 fields and container stands of Quercus spp. were infested by at least one Phytophthora species involved in widespread decline and dieback of mature oak stands. In 10 stands, more than one oak pathogen was found.

\subsubsection{Fields and container stands of other broadleaved species}

Sixty other broadleaved woody species from 39 genera in 24 families widely used for forest, riparian, amenity and landscape plantings were surveyed in 232 fields and container stands of 123 nurseries in 15 countries. Seventeen Phytophthora species and three informally designated Phytophthora taxa were detected in 195 stands (84.1\%) of 104 nurseries (84.6\%) (Fig. 3e; Tables 2 and S5). The most common species were P. cactorum, P. plurivora and P. cinnamomi. Five Phytophthora spp. were isolated from 18 of 26 nursery fields of nine Acer spp. with P. plurivora and P. cactorum being the most common. In 13 of the 14 Arbutus unedo stands tested in five countries, and in the 10 tested stands of I. aquifolium in Italy, Poland and Spain, P. cinnamomi and a range of other Phytophthora spp. were found. In Finland and Poland, P. cactorum was recorded in 14 of 20 forest nursery fields of Betula pendula tested. Five of the nine fields of Fraxinus excelsior in Germany and Poland were infested by P. plurivora and P. cambivora. Four and five Phytophthora spp., respectively, were present in six of the seven Juglans regia fields and in all seven container stands of Laurus nobilis sampled in five countries. Ten of 13 stands of five Prunus spp. in six countries were infested by P. cambivora and five other Phytophthora species. In $74 \%$ of 19 Tilia fields in Germany and Poland, P. cactorum and P. plurivora and another six Phytophthora spp. were found (Table S5). 
142
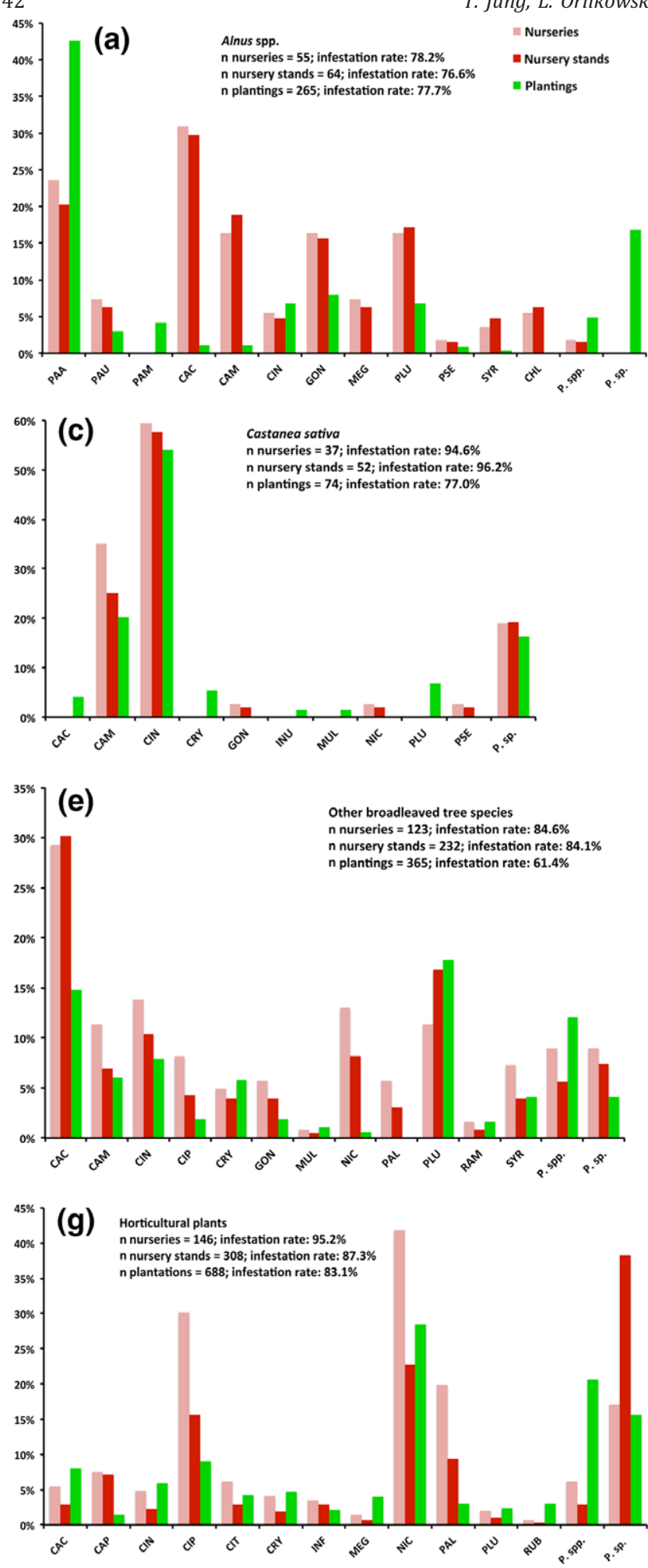

\section{B. Henricot et al.}
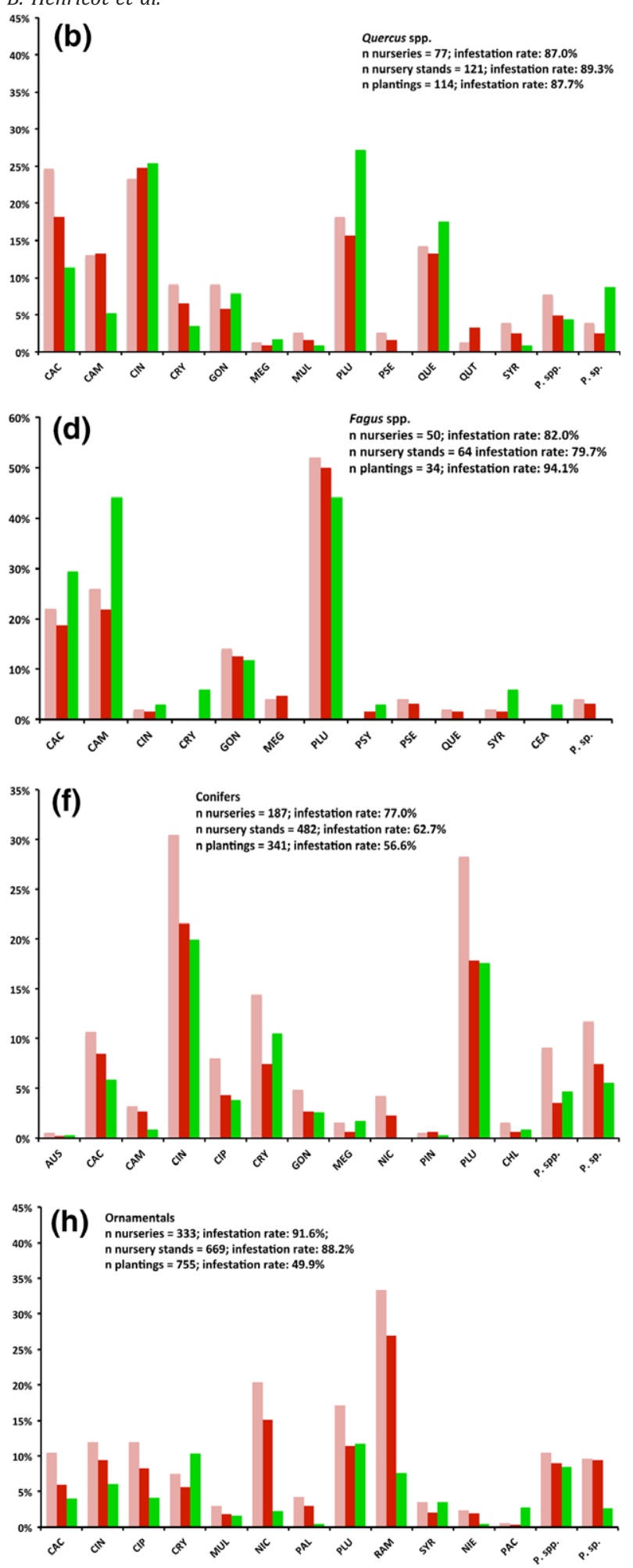

Fig. 3. Diversity and frequency of Phytophthora taxa in a: 64 nursery stands and 265 plantings of a: Alnus spp. in 10 European countries (AT, CZ, DE, ES, GB, HR, HU, PL, PT, SE); b: 121 nursery stands of 11 Quercus spp. in eight European countries (DE, ES, FR, IT, NL, PL, PT, RS); c: 52 nursery stands and 74 plantings of Castanea sativa in 10 European countries (DE, FR, ES, GB, GR, HU, IT, PL, PT, SK); d: 64 nursery stands of Fagus sylvatica and $F$. orientalis and 34 plantings of $F$. sylvatica in eight European countries (AT, DE, ES, FR, GB, PL, SE, SK); e: 232 nursery stands of 60 other broadleaved tree and shrub species in 15 European countries (AT, CH, DE, ES, FI, FR, GB, GR, HR, HU, IT, NL, NO, PL, PT); f: 482 nursery stands of 45 conifer taxa in 12 European countries (AT, DE, ES, FR, GB, HR, HU, IT, NO, PL, PT, SE); 308 nursery stands of 33 horticultural tree and crop taxa in eight European countries (ES, GB, HR, HU, IT, NO, PL, SE); g: 669 nursery stands of 142 ornamental plant taxa in 15 European countries (AT, CH, DE, ES, FI, FR, GB, GR, HR, HU, IT, NL, NO, PL, SE). Abbreviated Phytophthora names are explained in footnote 1 of Table 3. 


\subsubsection{Fields and container stands of conifer species}

A range of 21 Phytophthora taxa was detected in 302 of 482 stands of 45 conifer species tested in 187 forest, advanced tree and ornamental nurseries (Fig. 3f; Tables 2 and S6). Phytophthora cinnamomi and P. plurivora were most common. Eight of nine Abies alba fields in seven forest nurseries were infested with P. plurivora and four other Phytophthora spp. (Table S6). Thirteen Phytophthora species were detected in 47 of 51 fields and container stands of C. lawsoniana in 44 nurseries with P. cinnamomi, P. plurivora and P. cryptogea being the most common. All seven nursery fields of Larix decidua tested in Austria and Poland were infested; P. cactorum was most common. Of 21 Picea abies forest nursery stands in Germany and Poland, 12 were infested by five Phytophthora species with P. plurivora, P. cambivora and P. gonapodyides being the most frequent. In contrast, only P. citrophthora was found in five of 28 ornamental P. abies fields in Poland. Twelve Phytophthora species were isolated from 89 of 132 nursery stands of 13 Pinus spp. in 15 countries (Table S6). Most frequent were P. cinnamomi, P. cactorum, P. cryptogea and P. plurivora. In five Mediterranean countries, $29.4 \%$ and $26.5 \%$ of the 34 nursery stands of Pinus brutia, Pinus elliottii, Pinus halepensis, Pinus pinaster and Pinus pinea were infested by P. cinnamomi and P. cryptogea, respectively. Phytophthora cinnamomi was also isolated from nine of 17 container stands of P. radiata in 11 Spanish nurseries, while 24 of 37 Pinus sylvestris stands in five countries were infested by P. cactorum, $P$. plurivora and another four Phytophthora taxa. Phytophthora cinnamomi and P. plurivora were also present in seven of 10 forest nursery stands of Pseudotsuga menziesii in France, Germany and Spain. Eleven Phytophthora species, including P. cinnamomi and P. plurivora, were recovered from 30 of 50 T. baccata nursery stands sampled in 10 countries. In 81 nursery stands of Thuja occidentalis and Thuja plicata tested in seven countries, the infestation rate was $43.2 \%$, with Phytophthora plurivora and P. cinnamomi being the most common. Lowest infestation rates were found in 57 stands of Picea omorica and P. glauca and 40 stands of Juniperus spp.

\subsubsection{Summary of Phytophthora incidence in fields and container stands of forest nurseries}

Data on the occurrence of Phytophthora species from all forest stands of Alnus, Castanea, Fagus, Quercus, other broadleaved woody species and conifers are summarized in Fig. 4.

In the 486 fields and container stands of 77 tree and shrub species tested in 165 forest nurseries of 13 countries, 26 Phytophthora taxa were isolated from 396 stands in 155 nurseries. The most common species were P. cinnamomi, P. cactorum, P. plurivora and P. cambivora.

\subsubsection{Fields and container stands of horticultural species}

Thirty-three horticultural crop and fruit tree species in 22 genera were surveyed in 146 nurseries in eight countries. Eighteen Phytophthora taxa were recovered from 29 plant species in 268 of 308 stands (Fig. 3g; Tables 2, S7). Phytophthora nicotianae, P. citrophthora and P. palmivora were most common. Almost all 67 nursery stands of six Citrus spp. and Poncirus trifoliata $\times C$. sinensis in Italy and Spain were infested by P. nicotianae and P. citrophthora. Moreover, P. palmivora was isolated

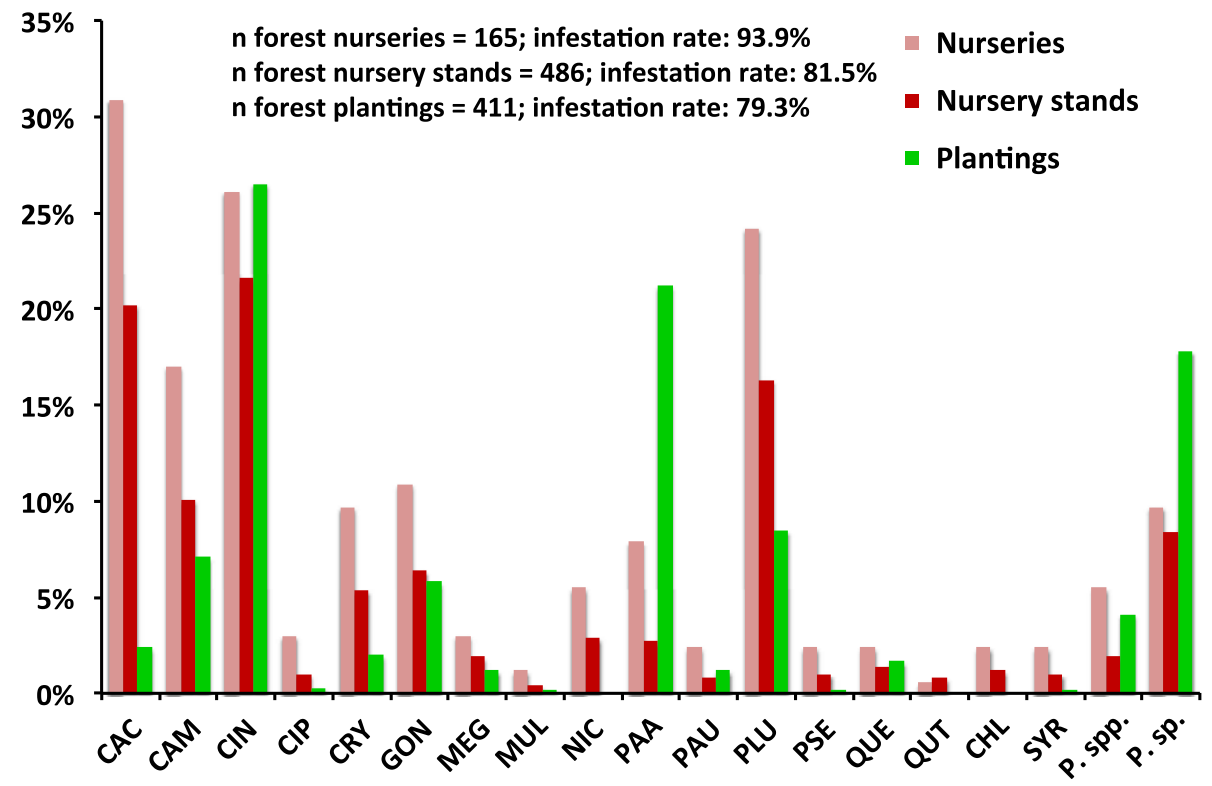

Fig. 4. Diversity and frequency of Phytophthora taxa in 486 forest nursery stands of 74 tree and shrub species in 14 European countries (AT, DE, ES, FI, FR, GB, HR, IT, PL, PT, RS, SE, TR, UA) and in 411 forest plantings of 32 tree and shrub species in 13 European countries (AT, CZ, DE, ES, FI, GR, HU, IT, PL, PT, RS, SE, SK). Abbreviated Phytophthora names are explained in footnote 1 of Table 3. 
from all 29 nursery stands of Olea europea in Italy. Phytophthora spp. which can attack forest trees were isolated from $25.5 \%$ of horticultural nursery stands (P. cactorum, P. cinnamomi, P. citrophthora, P. cryptogea, P. plurivora, P. syringae, P. ramorum).

\subsubsection{Fields and container stands of broadleaved ornamental species}

Surveys of 142 broadleaved ornamental species from 118 genera were performed in 660 stands of 333 nurseries in 15 countries; 33 Phytophthora taxa were recovered from 132 plant species in 582 stands of 305 nurseries (Fig. 3h; Tables 2 and S8). The most common isolations were of P. ramorum, P. nicotianae, P. plurivora, P. cinnamomi and P. citrophthora. Phytophthora ramorum was particularly common in 177 stands that included Camellia, Pieris, Rhododendron and Viburnum species and varieties. The ornamental species tested were too numerous to present full results here; details are given in Table S8. However, 556 of the 660 ornamental stands contained at least one of 19 Phytophthora taxa known to damage a wide range of native European trees and shrubs and exotic plantation trees. In $11.8 \%$ and $2.9 \%$ of these stands, two and three of these Phytophthora species, respectively, were found, while 1.4\% contained four or five Phytophthora spp.

\subsection{Health condition and symptoms on nursery plants}

Apart from damping-off of a few-month-old seedlings, scattered chlorosis and dieback of older plants due to root and collar rot, and scattered leaf necrosis and shoot dieback of Rhododendron species and hybrids, the majority of tested nursery plants in all nurseries in temperate climates appeared visually healthy. The following exceptions are noteworthy:

- After heavy rain, root and collar rot by P. cactorum, P. cambivora and P. plurivora caused scattered or patchy wilting and mortality of 1- to 3-year-old F. sylvatica seedlings in seven German forest nurseries (Fig. 5a).

- In seven Finnish forest nurseries, collar rot lesions on B. pendula seedlings caused by $P$. cactorum were detected in annual inspections between 1991 and 2004.

- In Poland, root rot, chlorosis, wilting and mortality caused by P. cactorum and P. plurivora occurred in patches of forest nursery seedlings of A. alba, F. sylvatica, B. pendula, A. glutinosa and Sorbus aucuparia during hot periods in summer.

- One- to three-year-old plants of A. glutinosa appeared vigorous and non-symptomatic. However, in several German nurseries infested by PAA, bark necrosis developed at the collar or on main roots of previously non-symptomatic plants after 1 week of flooding in baiting tests (Fig. 5b).

- In one German ornamental nursery, over 50\% of 200000 Calluna vulgaris seedlings succumbed to root infections caused by P. cinnamomi and P. plurivora.

In Mediterranean climates and in Atlantic regions of north-western Spain, typical above-ground symptoms, root and collar rot and scattered or patchy mortality were observed on a wide range of woody and herbaceous species in the majority of tested nurseries (Figs. 5c-g).

\subsection{Surveys in forest, riparian, amenity, landscape, horticultural and ornamental plantings}

\subsubsection{Diversity and distribution of Phytophthora species and infestation rates in plantings}

In total, 46 Phytophthora species plus five informally designated and five new Phytophthora taxa were isolated from 1667 of 2525 plantings tested in 20 European countries (Fig. 6; Table 3). Infestation levels of forest, riparian, amenity and landscape, horticultural and ornamental plantings were 79.3, 94.0, 56.6, 83.1 and 49.9\%, respectively. Numbers of Phytophthora species detected varied considerably, depending on the plant species. High diversity occurred in plantings of $T$. baccata (18 taxa), A. glutinosa (14), Rubus idaeus (13), Q. robur (12), Prunus laurocerasus (10), F. sylvatica (9) and C. lawsoniana (9). Phytophthora diversity in plantings depended on numbers of plant species tested. Greatest diversity was in a British ornamental and amenity planting where 15 different Phytophthora taxa were isolated from 33 different species and varieties of plants. A Croatian ornamental and amenity planting had nine Phytophthora spp. from 11 plant species and the two Slovakian landscape plantings each had seven Phytophthora taxa from 32 and 15 plant species, respectively.

In the 1667 infested plantings, 2227 different Phytophthora-planting associations were found, of which 2016 were identified to species level (Fig. 6; Table 3). Multiple isolates of a Phytophthora taxon from the same planting site were considered as a single record.

Invasive pathogens with wide host range, including P. plurivora (11.2\% of all plantings; 147 plant taxa), P. cinnamomi (10.1\%; 65 plant taxa), P. nicotianae (8.5\%; 34 plant taxa), P. cryptogea (6.9\%; 111 plant taxa) and P. cactorum (6.7\%; 97 plant taxa), were most common (Fig. 6; Tables 3, S1-S3, S9-S13). PAA was the only host-specific species with a relatively high isolation frequency. Isolations of P. gregata, P. sansomeana, P. rosacearum and P. taxon 'Ceanothus' were first records for these four pathogens from ornamental woody plants in Europe (Tables S3, S10-S13). Moreover, P. multivora, P. pini, P. polonica, P. pseudosyringae, P. psychrophila, P. quercina, P. tentaculata, P. tropicalis, P. uliginosa and P. taxon 'Forestsoil' were recorded from plantings in Europe for the first time (Tables 3, S1, S3-S4, S9-S12). Isolations of P. erythroseptica from seven ornamental host species, P. porri from Sambucus sp. and P. rubi from nine host species, all in the UK, were first records for these pathogens from woody plant species (Tables S10-S13). Phytophthora taxon 'gregata-like' from Abies nordmanniana in Austria and P. taxon 'organica' from Sambucus nigra and B. pendula in Germany, P. taxon 'porri-like' from Penstemon sp. in the UK, P. taxon 'sansomeana-like' from Prunus domestica trees in Germany and P. taxon 'sojae-like' from Albizzia julibrissin trees in Croatia were previously unrecorded taxa. 

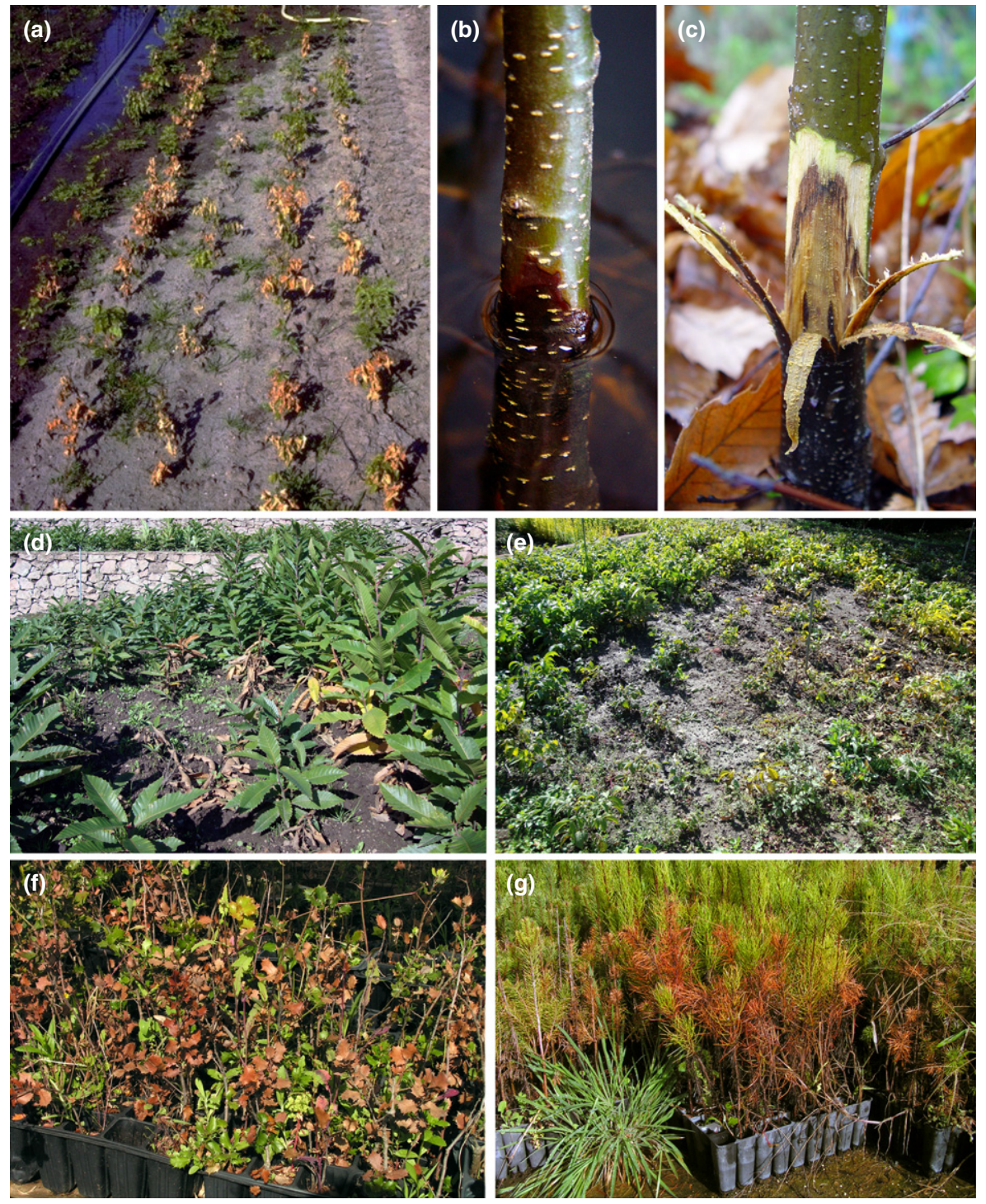

Fig. 5. Phytophthora symptoms of both field-grown and containerized forest nursery stock; a. Patch dieback and mortality of 2-year-old Fagus sylvatica seedlings caused by Phytophthora cambivora in Northern Germany; b. Collar rot caused by $P . \times$ alni after 1 week flooding on a visually healthy 2-year-old Alnus glutinosa seedling in Eastern Germany; c. Collar rot caused by P. cinnamomi on a 2-year-old Castanea sativa in Sardinia; d. Patch dieback and mortality caused by P. cambivora and P. cinnamomi in a C. sativa field in Sardinia; e. Patch dieback and mortality caused by P. cinnamomi in a Juglans regia field in Sardinia f. Wilting and mortality of 2-year-old Quercus ilex in Extremadura caused by P. cambivora; g. Chlorosis, wilting and mortality of Pinus halepensis in Extremadura caused by P. cryptogea and $P$. taxon 'PgChlamydo'.

The planting surveys confirmed known or assumed host specificities or preferences of several Phytophthora taxa, including PAA, PAM and PAU and Alnus spp., P. ilicis and I. aquifolium, P. quercina and Quercus spp., and P. ramorum and Camellia, Pieris, Rhododendron and Viburnum. However, in one amenity planting in the UK, PAA was present in the rhizosphere of the non-host species T. baccata.

Nineteen of the 56 Phytophthora taxa were found in all three major climatic regions. Frequencies and composition of the Phytophthora populations in plantings differed between the climatic regions (Fig. 7). Of the 304 surveyed plant species, 21 were common to all three climatic regions, while 14 and 12 species were shared between the Atlantic, Mediterranean and subcontinental to continental regions, respectively; plantings in the latter two regions had 10 plant species in common. In the Atlantic climate, 38 Phytophthora taxa were detected in 935 of 1798 sampled plantings (Fig. 7 a). Phytophthora species with predominantly aerial lifestyles and frost-sensitive species accounted for $11.6 \%$ and $23.6 \%$ of Phytophthora-planting associations, respectively. The most common species were P. cinnamomi, P. plurivora and P. cryptogea (Fig. 8). Nine taxa (P. austrocedrae, P. erythroseptica, P. hibernalis, P. ilicis, P. kernoviae, P. porri, P. primulae, $P$. pachypleura and $P$. taxon 'porri-like') were exclusively isolated from plantings in Atlantic regions. In subcontinental to 


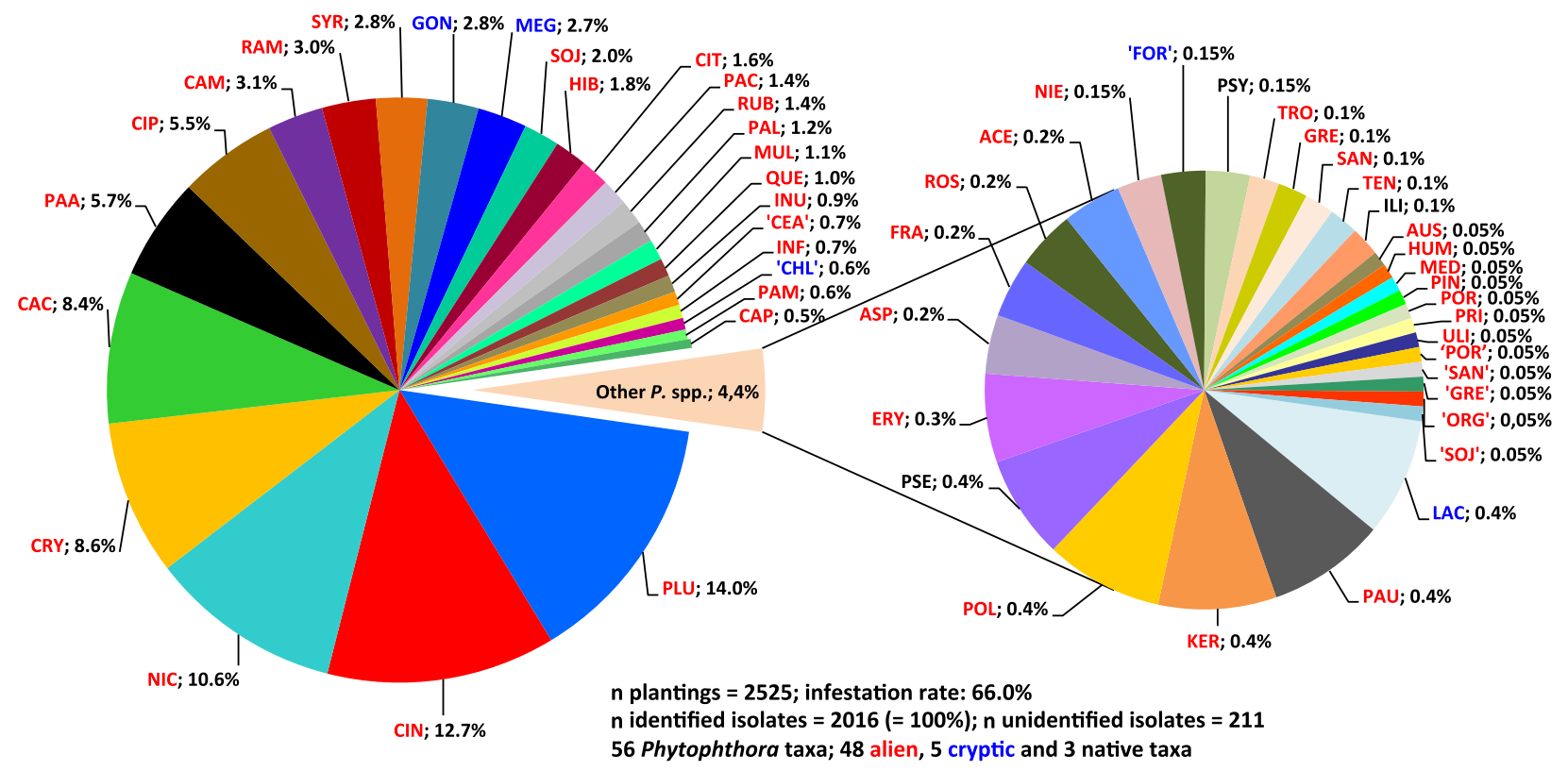

Fig. 6. Diversity and frequency of alien, native and cryptic Phytophthora taxa in 2525 forest, riparian, amenity, landscape and ornamental plantings, and horticultural plantations of 478 broadleaved and conifer tree, shrub and herbaceous taxa (species, cultivars, hybrids) in 20 European countries. Multiple isolates of a Phytophthora taxon from the same nursery stand were considered as one record. Abbreviated Phytophthora names are explained in footnote 1 of Table 3.

continental regions, 31 Phytophthora taxa were recovered from 314 of the 319 plantings surveyed (Fig. 7b). Only two predominantly aerial species, P. ramorum and P. pseudosyringae, were infrequently found while frost-tolerant species occurred in $98.4 \%$ of the plantings and accounted for $98.8 \%$ of identified Phytophthora-planting associations. Phytophthora plurivora, P. cactorum and PAA were most common (Fig. 7b). Thirty-seven Phytophthora taxa occurred in the 408 Mediterranean plantings sampled (Fig. 7c). The proportion of frost-sensitive thermophilous species was 45.9\%, whereas predominantly aerial Phytophthora species accounted for only 6.4\% of Phytophthora-planting associations. Phytophthora nicotianae was the most common species followed by P. citrophthora. Nine Phytophthora taxa (P. acerina, P. asparagi, P. gregata, P. humicola, P. medicaginis, P. rosacearum, P. sojae, P. tentaculata and P. taxon 'sojae-like') were only found in Mediterranean plantings (Fig. 7c).

\subsubsection{Alnus plantings}

Of 265 Alnus plantings, 206 were infested by a total of 15 Phytophthora taxa (Fig 3a; Tables 3 and S1). In 213 forest plantings, the 48 riparian plantings and the four amenity plantings of A. glutinosa and A. incana in eight of 11 countries, PAA was the most frequently isolated species. In Bavaria, necrotic collar lesions yielded PAA in 63 of 70 forest and riparian plantings surveyed (Tables 3 and S1). PAM and PAU were isolated from collar rot lesions in 11 plantings in Germany, Spain and the UK, and in eight plantings in Austria, Croatia, Germany, Poland and Spain, respectively (Tables 3 and S1). In five plantings in Bavaria and Austria, P. plurivora was the exclusive causal agent of collar rot lesions and in another six plantings $P$. plurivora occurred with PAA.

\subsubsection{Castanea sativa plantings}

In total, 10 Phytophthora species were isolated from 50 of the 62 forest plantings and from seven of the 12 amenity and landscape plantings of C. sativa in Germany, Greece, Italy, Portugal, Slovakia, Spain and the UK (Fig. 3c; Tables 3 and S2). Phytophthora cinnamomi and P. cambivora were found in 54.1\% and 20.3\% of Castanea plantings, respectively.

\subsubsection{Fagus sylvatica plantings}

Eleven Phytophthora species were isolated from soil samples and collar rot lesions in 32 of the 34 forest and amenity plantings of $F$. sylvatica surveyed in Germany, Slovakia, Spain, Sweden and the UK. Phytophthora cambivora and P. plurivora were most common followed by P. cactorum (Fig. 3d; Tables 3 and S3). From 88.2 and 29.4\% of the beech plantings, one and two of these three beech pathogens, respectively, were recovered (Table S3). 


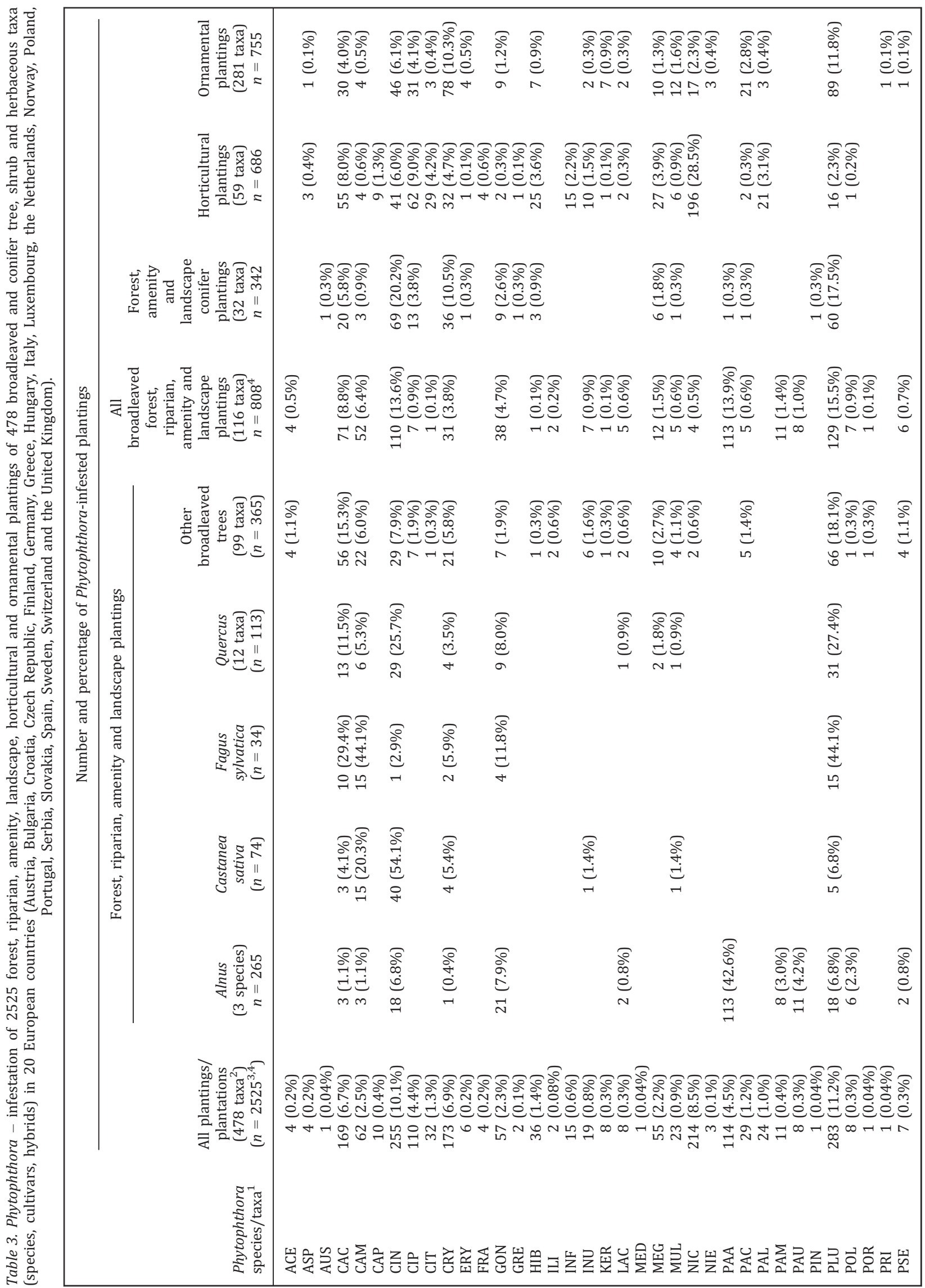




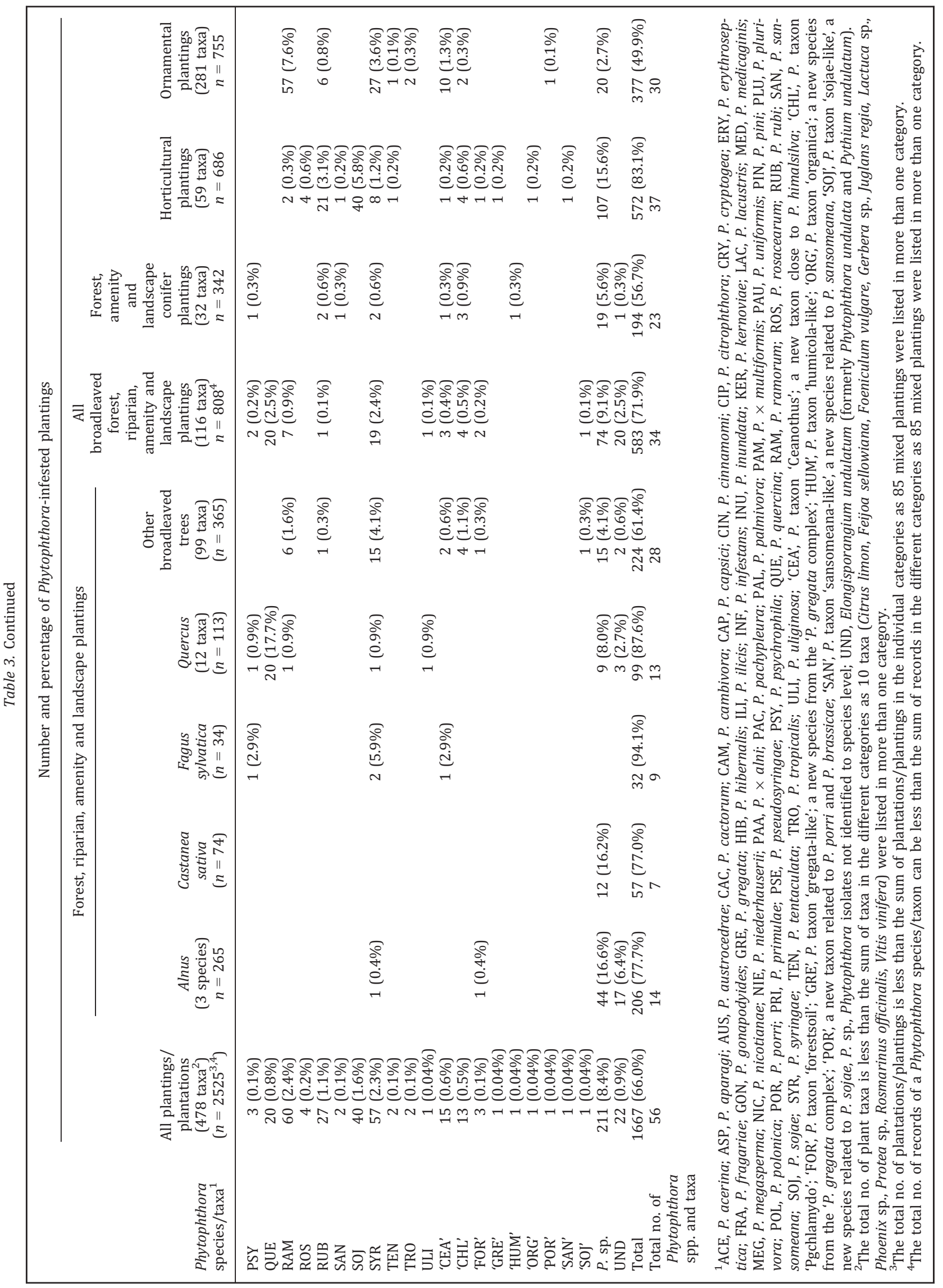



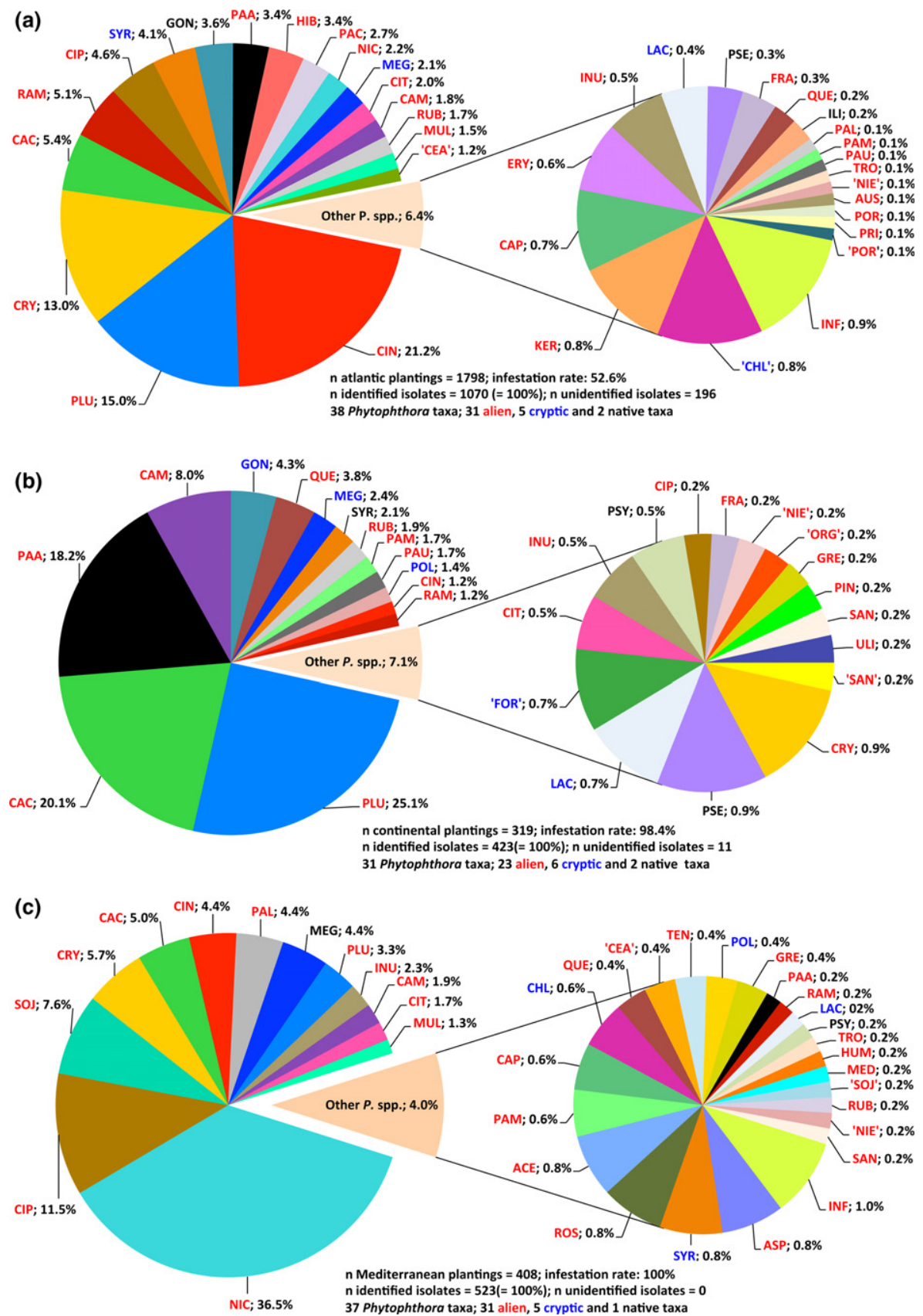

Fig. 7. Diversity and frequency of alien, native and cryptic Phytophthora taxa in riparian, amenity, landscape and ornamental plantings, and horticultural plantations in different climatic regions of Europe; a: 1798 plantings in Atlantic regions (ES, FR, GB, NL); b: 408 plantings in Mediterranean regions (ES, FR, GR, IT, HR, PT, TR); c: 319 plantings in subcontinental to continental regions (AT, CH, DE, FI, HU, NO, PL, RS, SE, UA). Multiple isolates of a Phytophthora taxon from the same nursery stand were considered as one record. Abbreviated Phytophthora names are explained in footnote 1 of Table 3.

\subsubsection{Quercus plantings}

Seventy-three forest and 40 amenity and landscape plantings of 12 Quercus taxa in 10 countries were surveyed, and 101 were infested by a total of 15 Phytophthora species (Fig. 3b; Tables 3 and S9). Phytophthora plurivora, P. cinnamomi and $P$. quercina were most common over all plantings surveyed, but frequencies differed between climatic regions. Phytophthora cinnamomi was isolated from 18 of 21 Mediterranean oak plantings in Italy, Spain and Portugal, and from 11 of 35 Atlantic oak plantings in Spain and the UK, but was not found in subcontinental to continental plantings (Table S9). In contrast, $P$. plurivora and P. quercina were present in 51.7 and 29.3\%, respectively, of subcontinental to continental oak plantings in six countries, but rarely occurred in Mediterranean or Atlantic plantings (Table S9). Seventy-two of 113 oak plantings were 

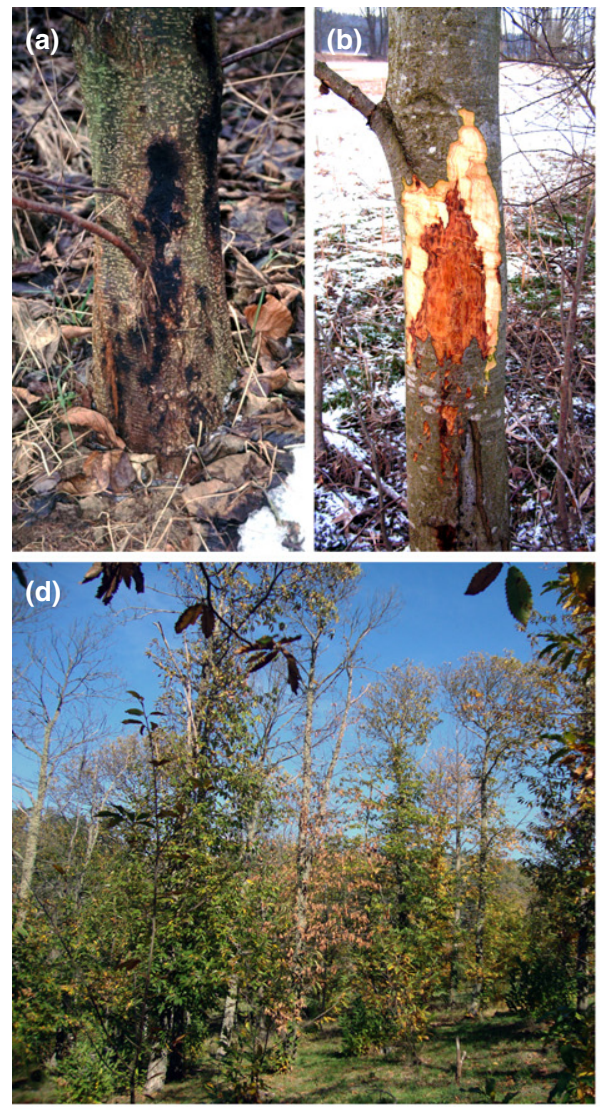

(f)

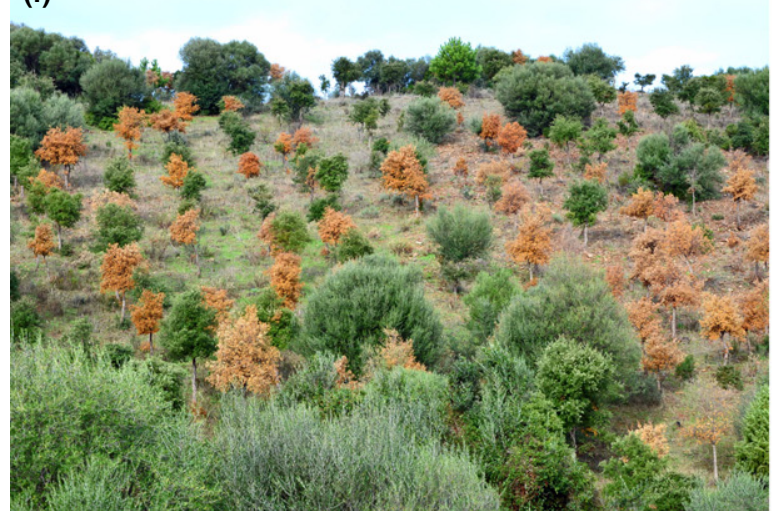

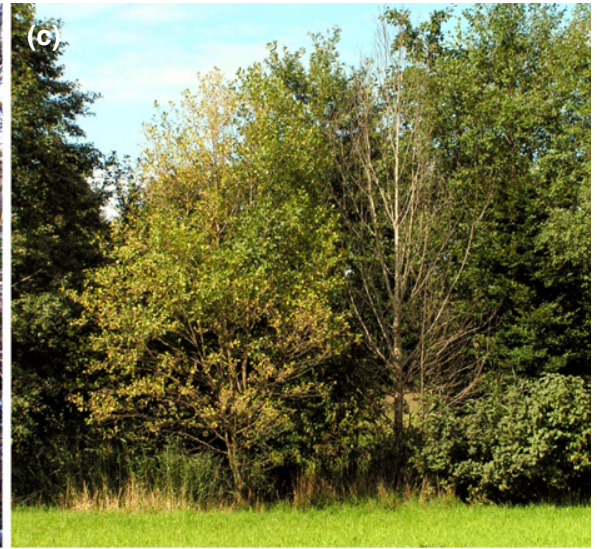
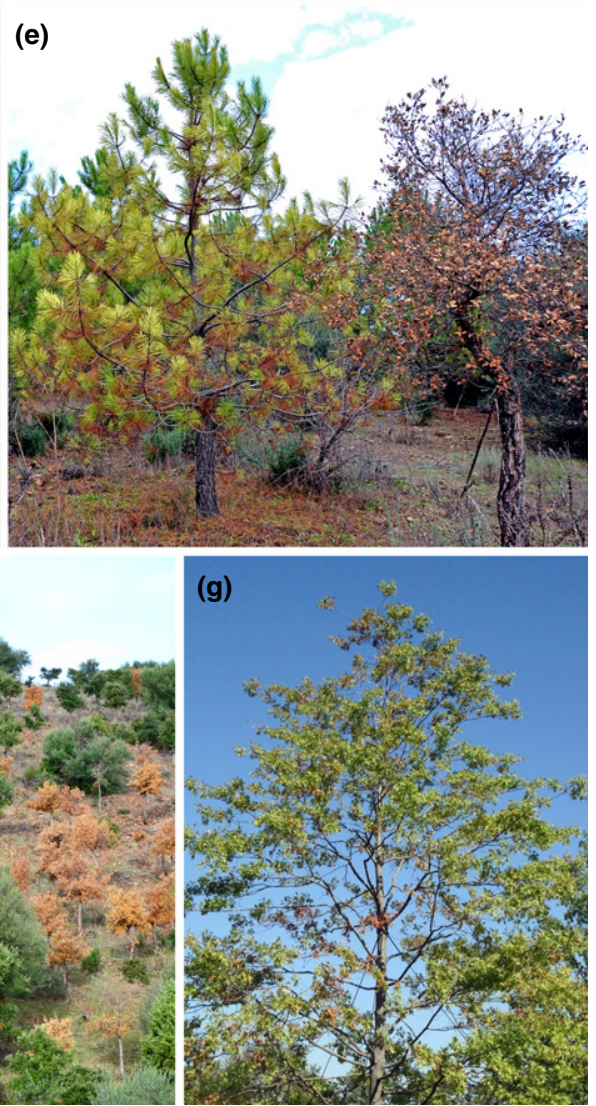

Fig. 8. Phytophthora symptoms in forest and landscape plantings; a. Collar rot with tarry spots on the outer bark caused by Phytophthora $\mathrm{x}$ alni (PAA) on 10-year-old Alnus glutinosa in Bavaria; b. Orange-brown, tongue-shaped lesion of inner bark caused by PAA on a 12-year-old Alnus incana in Bavaria; c. Chlorosis, dieback and mortality of 8-year-old A. glutinosa in Bavaria caused by PAA; d. Dieback and mortality caused by P cambivora and P. cinnamomi in a 12-year-old Castanea sativa planting in Sardinia.; e. Sudden wilting and mortality of Quercus suber and thinning, chlorosis and small-sized needles of Pinus pinaster caused by P. cinnamomi in a 10-year-old afforestation in Sardinia; $\mathrm{f}$. Sudden wilting and mortality of Quercus ilex and Q. suber caused by P. cinnamomi in a 10-year-old afforestation in Sardinia; g. 25-year-old Quercus palustris in a recently established landscape planting in Slovakia showing thinning, chlorosis and dieback of the crown due to fine root losses caused by P. cactorum, P. cambivora, P. plurivora and P. quercina.

infested by at least one Phytophthora species associated with decline of mature oak stands. In 12 plantings, two of these pathogens were found (Fig. 5b; Table S9).

The Département de la Santé des Forêt (DSF) database contained 497 reports of oak (mainly Q. robur) stands with health problems from SW France for which establishment by either planting or seed regeneration was documented. With 14 of 18 stands suffering from P. cinnamomi-induced cankers, the majority of reports were from planted stands, while only $14 \%$ of reports dealing with a health problem other than P. cinnamomi referred to plantings. The odds ratio was 21.5 (likelihood chi-square $=35.1, \mathrm{p}<0.001$ ). Mean prevalence of cankered trees in plantings was $11 \pm 3 \%$ (range 2-22\%). 


\subsubsection{Plantings of other broadleaved species}

Twenty-eight Phytophthora taxa were recovered from 224 of 365 forest, riparian, amenity and landscape plantings, with 99 other broadleaved tree and shrub species surveyed in 16 countries (Fig. 3e; Tables 3 and S10). Phytophthora plurivora and $P$. cactorum were the most common species isolated. Thirty-seven of 47 plantings of 10 Acer spp. were infested, with $P$. plurivora, P. cactorum and P. cambivora the most frequent species present (Table S10). Phytophthora spp. were isolated from 15 of 17 plantings of Aesculus hippocastanum tested with P. cactorum and P. plurivora being the most common (Table S10). Seventeen of 18 plantings of Tilia spp. were infested, P. cactorum and P. plurivora being the most frequent. In eight of 14 A. unedo plantings in Portugal and the UK, P. cinnamomi and six other Phytophthora species were found. Also five of the nine plantings of Juglans regia and eight of the nine plantings of Laurus nobilis in Spain and the UK hosted Phytophthora with P. cinnamomi being the most common in both. In six countries, 36 of 58 sampled plantings of eight Prunus spp. were infested by 12 Phytophthora taxa (Table S10).

\subsubsection{Conifer plantings}

In 192 of 342 plantings of 32 conifer species in 11 countries, 23 Phytophthora taxa were detected: P. cinnamomi (11 species), P. plurivora (17 species) and P. cryptogea (10 species) were the most common (Fig. 3f; Tables 3 and S11). Amongst the conifer species or genera with over five surveyed stands, highest infestation was found in plantings of $C$. lawsoniana, Pinus spp., T. occidentalis, T. plicata and T. baccata (57-77\%).

\subsubsection{Summary of Phytophthora incidence in forest plantings}

Four hundred and eleven afforestations and reforestations including two Alnus spp., C. sativa, F. sylvatica, six Quercus spp., 11 other broadleaved tree species and 12 conifer species were surveyed in 13 countries, with 23 Phytophthora taxa isolated from 326 plantings. The most common were P. cinnamomi, PAA, P. plurivora, P. cambivora and P. gonapodyides (Fig. 4).

\subsubsection{Horticultural plantings}

Thirty-seven Phytophthora taxa were found in 572 of 688 plantings of 59 fruit tree and horticultural crop species surveyed in 11 countries (Fig. 3g; Tables 3 and S12). Phytophthora nicotianae and P. citrophthora occurred frequently in the 244 Citrus and Poncirus plantings tested (Tables 3 and S12). Phytophthora nicotianae was present in all Citrus plantings in Italy but only in three of the 75 plantings in Galicia, north-western Spain. Also P. citrophthora was more frequent in Citrus plantations in Italy than in Galicia, where P. hibernalis and P. citricola were more common (Table S12). Five Phytophthora species were detected in 23 of 33 apple orchards tested in seven countries; $P$. cactorum was most common, followed by $P$. plurivora. Surveys of 36 olive tree plantings in Croatia, Italy and Spain revealed a total of nine Phytophthora species in all plantings with P. palmivora and P. inundata being the most frequent. The nine orchards of $J$. regia surveyed in Greece, Italy and Slovakia were infested by P. cactorum and P. cambivora. In seven countries, 13 Phytophthora taxa were isolated from 21 of 36 tested Prunus orchards. The most common were P. cactorum and P. taxon 'PgChlamydo' in Prunus avium, P. cactorum and P. plurivora in Prunus domestica, and P. megasperma and P. inundata in Prunus persica. In a German orchard, both $P$. sansomeana and P. taxon 'sansomeana-like' were isolated from P. domestica (Table S12). In total, 14 Phytophthora taxa were present in 36 of 56 raspberry plantings sampled in four countries, with $P$. rubi and $P$. megasperma being the most common.

\subsubsection{Ornamental plantings of broadleaved species}

In total, 755 ornamental plantings of 281 broadleaved woody and herbaceous species were sampled in eight countries. Thirty Phytophthora taxa were isolated from 377 plantings (Fig. 3h; Tables 3 and S13). Most widespread were P. plurivora and $P$. cryptogea. Amongst species sampled in over five plantings, the highest infestation rates were found in Buxus sempervirens, Camellia japonica, Lavandula spp., Pieris spp., Rhododendron spp., Rosa spp., Rosmarinus officinalis and Viburnum spp. (Table S13). The ornamental species tested were too numerous to present full results here; details are given in Table S13. However, of 755 ornamental plantings tested, 339 had at least one of 21 Phytophthora taxa known to damage a wide range of European and exotic tree and shrub species. Approximately $10 \%$ of the tested stands had more than one of these aggressive tree pathogens present. In seven countries, 96 plantings of 13 Rhododendron species and various Rhododendron hybrids were surveyed, with a total of 13 Phytophthora taxa isolated from 72 plantings. Most common was $P$. ramorum followed by $P$. plurivora and $P$. syringae.

\subsection{Health condition and disease symptoms of plants in various types of plantings}

Because of the diversity of plant species and the large number of plantings tested, observed symptoms are presented for only the most commonly sampled plant species.

All 152 forest, riparian and amenity plantings of Alnus glutinosa, A. incana and A. cordata from which PAA, PAU, PAM, $P$. cinnamomi or P. plurivora were isolated had necrotic lesions with tarry or orange-brown spots on the outer bark and 
orange, flame-shaped discoloration of the inner bark, extending from the collar to $1.5 \mathrm{~m}$, and small, chlorotic and sparse foliage, dieback, heavy fructification with unusually small cones and scattered or patchy mortality were found (Fig. 8a-c). Disease incidence was highest in PAA-infested stands. In a detailed survey of 2219 five- to 17-year-old A. glutinosa trees in 15 PAA-infested forest plantings in Bavaria, collar rot incidence was $52.5 \pm 23.8 \%$ in 2003, increasing to $62.3 \pm 20.8 \%$ in 2004. In the same period, overall mortality increased from $2.8 \%$ to $5.3 \%$.

In all 50 Phytophthora-infested forest plantings of $C$. sativa in Greece, Italy, Portugal and Spain and in six of the 12 amenity plantings, most of the 5- to 28-year-old trees showed severe root and collar rot symptoms, with small and sparse foliage, dieback and mortality (Fig. 8d).

In 31 of 32 forest and amenity plantings of Quercus ilex, Q. suber and Q. faginea tested in Italy, Portugal and Spain, extensive fine root losses mainly caused by P. cinnamomi and severe crown symptoms, including stunted growth, thinning, dieback and wilting and high mortality levels, were observed (Fig. 8e-f). In a 14-year-old, 850-ha afforestation in southwestern Andalusia, $10 \%$ of Q. ilex trees were dead and almost all living trees were in decline, 50\% showing over $40 \%$ defoliation. In 2008/2009 in a national park in Extremadura, 260 ha of Eucalyptus camaldulensis plantations were harvested and re-forested with 2-year-old Q. ilex. In 2011, P. cinnamomi had caused severe dieback and mortality in over 50\% of randomly selected plants. In Sardinia, P. cinnamomi caused over 50\% mortality in a 10 -year-old 70-ha afforestation of $Q$. ilex, Q. suber and Pinus pinaster following a wet spring in 2011 (Fig. 8e-f).

In 47 of 49 forest plantings of Q. petraea, Q. robur and Q. rubra in Germany, Poland, Serbia and Spain, and in all 36 amenity and landscape plantings of eight Quercus spp. in seven countries, scattered or patchy distributions of typical root and crown symptoms and mortality were found (Figs 8g, 9a).

In five 8- to 15-year-old afforestations on former agricultural land in Germany, 2000 trees of various broadleaved species were examined in 2003 and root and collar rot symptoms (Fig. 9b), with reduced growth, chlorotic foliage and dieback (Fig. 9c) caused by Phytophthora cambivora were found in $73.6 \%$ of the 1417 F. sylvatica trees tested. Similar symptoms were also common in most other forest and amenity plantings of $F$. sylvatica analysed in Germany, Slovakia, Spain, Sweden and the UK.

In 37 infested amenity and landscape plantings in five countries, A. hippocastanum, C. betulus, Tilia cordata, T. platyphyllos and T. $\times$ europaea showed extensive loss of fine roots, with thinning crowns, chlorosis and dieback (Fig. $9 \mathrm{~d}$ ). In some A. hippocastanum trees, bleeding bark lesions extended from the collar to $3 \mathrm{~m}$ stem height (Fig. 9e).

Most plantings of 10 Acer spp. in six countries had extensive loss of fine and lateral roots, collar rot, crown dieback and scattered mortality due to Phytophthora infections (Fig. 9f). In five afforestations in northern Germany, over $50 \%$ of 408 A. pseudoplatanus trees showed root and collar rot symptoms and crown decline caused by P. cambivora. Four Italian A. pseudoplatanus afforestations had similar symptoms caused by P. acerina.

Fine root losses, crown decline, wilting and scattered mortality occurred in most of the Phytophthora-infested forest, amenity and landscape plantings of C. lawsoniana (Fig. 9g), Juniperus spp., Sequoiadendron giganteum, Taxodium distichum, Taxus baccata, Thuja occidentalis and T. plicata in six countries. Collar rot of individual trees was infrequent. In several Phytophthora-infested afforestations of Pinus pinaster, P. halepensis fine root loss and symptoms of 'little leaf disease' were common (Fig. 8e).

Typical Phytophthora-related symptoms were also widespread in horticultural and ornamental plantings, but the number of affected plant species was too numerous to present data on symptoms or disease incidence of specific host plants.

\section{Discussion}

The surveys reported in this large-scale analysis of Phytophthora infestations in Europe clearly demonstrated that nursery stands across Europe are almost ubiquitously infested by a large array of Phytophthora species, confirming results from previous small-scale studies (Themann et al. 2002; Jung and Blaschke 2004; Jung 2009; Moralejo et al. 2009). In total, 49 Phytophthora taxa were recovered from $81 \%$ of the 1992 nursery stands in $91.5 \%$ of the 732 nurseries tested in 18 European countries. Frequencies of Phytophthora infestation in forest, advanced tree, horticultural and ornamental nurseries were comparable, ranging from 88.3 to $97.1 \%$ at the nursery level and from 78.6 to $92.3 \%$ at the level of the nursery stands. Mean infestation levels were almost identical in container stands and in fields with production of plants in soil. This result was surprising as in the latter production system an accumulation of soilborne Phytophthora species over years is inevitable if plants are regularly bought in from other nurseries and planted in these fields, whereas container production offers many options to avoid pathogen contamination. However, purchasing container plants from other nurseries without prior testing for potential Phytophthora infestations and generally poor nursery practices such as overly dense plantings and close proximity of various plant species enabling cross-infections, reuse of compost or plastic containers without sterilization, use of unfiltered surface water or recirculation of irrigation water without filtering or sterilization, storing containerized nursery stock on poorly drained surfaces or even on the ground, and collection of dead plants and plant debris near the production area all facilitate introduction, reintroduction and spread of Phytophthora spp. in container nurseries (Ferguson and Jeffers 1999; Themann et al. 2002; Pérez-Sierra and Jung 2013). Many of the container nurseries tested in the present work regularly purchased container plants from other nurseries. In addition, many of the poor nursery practices listed above were commonly observed. Infestation levels of nurseries were also independent of plant marketing category, a result that was not unexpected considering the fundamental changes in the nursery sector over the last three decades. Economic pressure and changes in consumer demands have stimulated consolidations through mergers and acquisitions creating larger companies, causing increased vertical specialization and complexity of the international plant distribution chain (Dehnen-Schmutz et al. 2010; Drew et al. 2010). Currently, wholesale, retail and administration nurseries are 

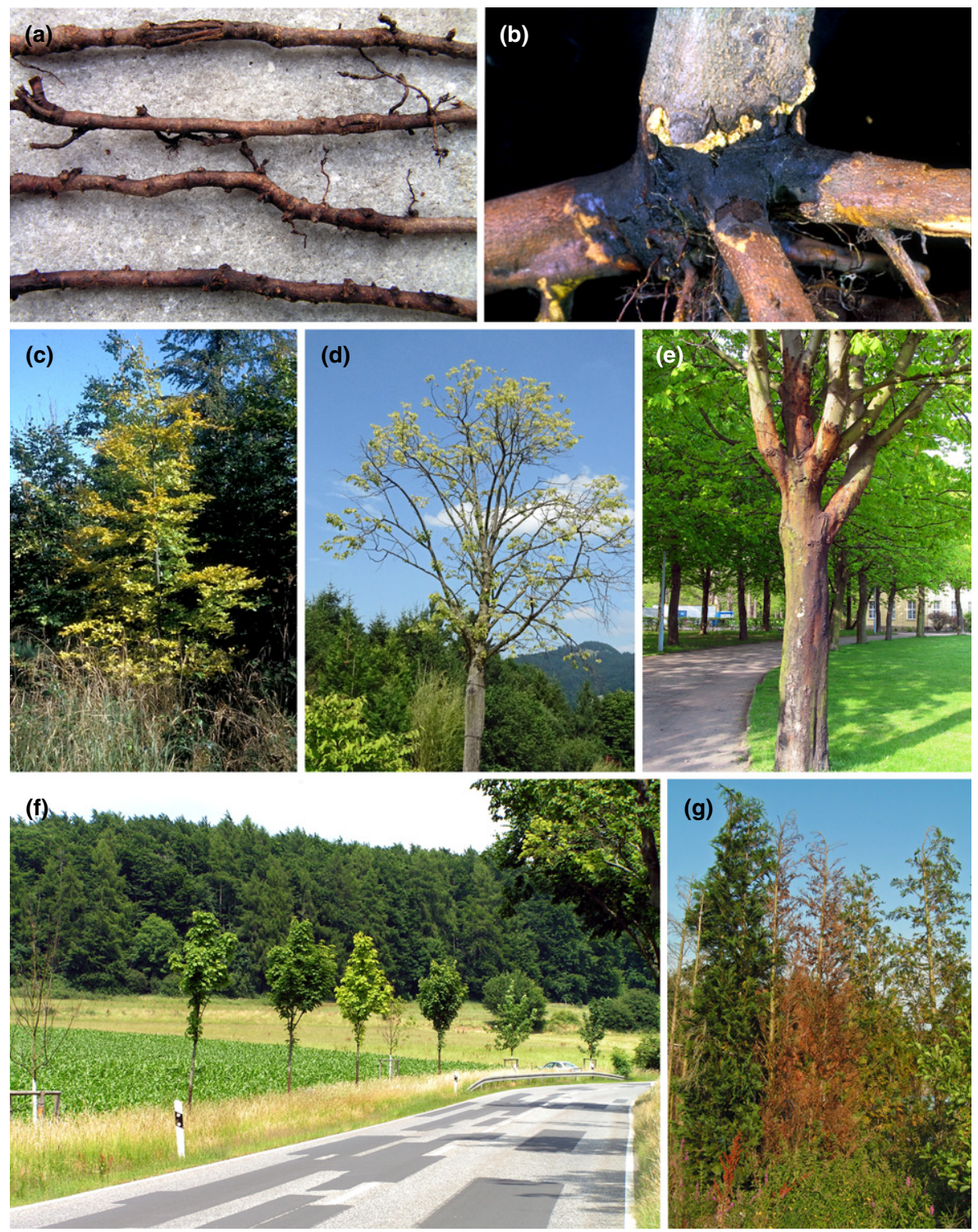

Fig. 9. Phytophthora symptoms in forest, amenity and landscape plantings in Germany; a. Small suberized roots of a 10-year-old Q. robur in a landscape planting with extensive losses of lateral roots and fine roots and open cankers caused by P. quercina and $P$. plurivora; $\mathrm{b}$. Girdling collar rot lesion caused by P. cambivora on F. sylvatica in a 10-year-old afforestation; c. Chlorosis and slow decline of a 12-yearold Fagus sylvatica in an afforestation due to root and collar rot caused by Phytophthora cambivora; d. 12-year-old Tilia platyphyllos in a landscape planting with advanced chlorosis, thinning and dieback of the crown due to severe fine root losses caused by $P$. cactorum and $P$. plurivora; e. 10-year-old Aesculus hippocastanum in an urban park with P. plurivora collar rot and orange exudations extending up to $4 \mathrm{~m}$ stem height; f. Dead and chlorotic Acer pseudoplatanus trees in a 5-km-long roadside planting severely infested by P. cambivora, P. plurivora and P. gonapodyides; g. 10-year-old landscape hedgerow planting of Chamaecyparis lawsoniana with thin chlorotic crowns (right side), wilting (centre) and mortality (left side) due to root rot caused by P. cryptogea.

almost exclusively reselling nursery stock bought in from a relatively low number of large producers with national and international distribution, from brokers or from other wholesalers and retailers. Due to intense vertical and horizontal trade, individual plants often flow largely unregulated through several nurseries both within and between countries before being sold to a consumer (Dehnen-Schmutz et al. 2010; Drew et al. 2010). Such a system provides optimal conditions for the rapid spread of soilborne pathogens like Phytophthora spp. which can be transported when suppressed by fungicides and fungistatic chemicals on non-symptomatic host plants or as passive hitchhikers on non-host plants (Brasier 2008; Pérez-Sierra and Jung 2013). In one Bavarian nursery for example, the oak-specific P. quercina was isolated from the rhizosphere of seedlings from the non-host species $F$. sylvatica sampled in a field where $Q$. robur was grown 2 years prior.

The risk of aggressive Phytophthora species spreading with visually healthy host plants is convincingly demonstrated by the work reported here and by Migliorini et al. (2015). Generally, the majority of nursery plants tested in intensively managed nurseries often with regular use of fungicides and fungistatic chemicals and professional irrigation regimes, avoiding 
wet or waterlogged soil conditions and wetting of above-ground plant organs, appeared visually healthy. As the European system of plant biosecurity is based principally on visual inspections for symptoms, it is impossible for both plant inspectors and buyers of plants to detect masked Phytophthora infestations (Jung and Blaschke 2004; Brasier 2008; Pérez-Sierra and Jung 2013). The weakness of the current system, discussed in detail below, is highlighted by the following striking examples taken from a long list of Phytophthora-infested non-symptomatic host plants or non-host plants detected in the European nursery trade during this work. In Greece, P. multivora and P. ramorum, both exotic wide host range pathogens aggressive on Rhododendron spp. in particular, were isolated in 2011 from visually healthy Rhododendron plants imported from Belgium and accompanied by EU plant passports (Table S8). In Croatia, a diverse population of 23 described species or designated taxa of Phytophthora including P. multivora, P. ramorum, recently introduced exotic species like $P$. parvispora and P. niederhauserii, and several previously unknown Phytophthora taxa were detected between 2007 and 2013 on plants imported from nurseries in Italy and the Netherlands which were also accompanied by EU plant passports (Tables S5-S8). The newly described P. pachypleura (Henricot et al. 2014) was isolated in an Italian nursery from A. japonica plants imported from a French nursery. In Bavaria and Austria, most Phytophthora-infested plants found in forest nurseries and nurseries producing large specimen trees originally came from producers in Northern and Western Germany or the Netherlands, before being grown for one or more years in the fields of retail nurseries. Long-distance spread of Phytophthora species with infested nursery stock was also demonstrated on other continents, including Australia, despite the strict quarantine regulations and extensive phytosanitary controls of nursery stock (Davison et al. 2006), and the United States, where P. ramorum was spread from ornamental nurseries in California and Oregon to nurseries in at least 14 eastern states of the US despite emergency quarantine regulations in place for this specific pathogen (Goss et al. 2009; Grünwald et al. 2012). In this instance, the pathogen was not intercepted during mandatory phytosanitary controls and evidence of spread came from molecular trace-back studies of already established P. ramorum populations (Goss et al. 2009). Using a network analysis, Pautasso et al. (2010) demonstrated that spread of P. ramorum in the UK also occurred via the nursery trade.

Even though the Phytophthora infestations would have been detected during the phytosanitary inspections at the exporting nurseries, transport and sale of most infested nursery plants could not have been prevented as only five Phytophthora species, P. fragariae, P. kernoviae, P. lateralis, P. ramorum and P. rubi, are included on the EPPO A2 quarantine list, despite the fact that many other exotic Phytophthora species are causing large-scale epidemic diebacks and mortality of forest trees in Europe (Brasier et al. 1993; Jung et al. 1996, 2000, 2013a; Vettraino et al. 2001, 2002; Streito et al. 2002; Balci and Halmschlager 2003a,b; Gibbs et al. 2003; Jung and Blaschke 2004; Jung 2009).

A key finding of the present study was that the most aggressive Phytophthora species to the respective tree or crop species were regularly found in both nursery stands and young plantings (Tables S1-S13). An invasive pathogen may be spread to natural forest stands several times, although it will not necessarily successfully establish. However, the specific life strategy of Phytophthora spp., based on highly resistant oospores facilitating long-term survival, chlamydospores for medium- and short-term survival, the multicyclic production of sporangia releasing motile zoospores able to infect healthy unwounded tissues of vigorous hosts, their often high aggressiveness, and the either wide host ranges or very specific adaptations to certain host plants, arguably make Phytophthora species the most notorious and successful invasive plant pathogens in existence (Erwin and Ribeiro 1996; Hansen et al. 2012; Jung et al. 2013a,b). Consequently, continuous highfrequency spread of these aggressive pathogens of trees and crops with infested nursery stock will inevitably lead to further large-scale establishment in forests, horticultural systems and the wider environment. This effect was convincingly demonstrated by a trace-back study in 75 river systems in Bavaria where mortality of natural riparian alder forests was almost exclusively found in rivers with the presence of $P . \times$ alni-infested alder plantings in their upper catchment areas (Jung and Blaschke 2004). Using the following line of reasoning, the results of the present nursery and planting surveys provide strong circumstantial evidence of high-frequency spread of Phytophthoras via infested nursery stock to the wider environment. The planting surveys demonstrated the presence of 56 Phytophthora species and taxa in $66 \%$ of over 2500 tested plantings. As all plants in planting sites came from nurseries whereas all nursery plants were seed-grown, the finding of similar mean infestation rates for forest (79.3\%), riparian (94\%) and horticultural plantings (83.1\%) on the one hand and nursery stands in forest (81.5\%), advanced tree (92.3\%) and horticultural $(90.5 \%)$ nurseries on the other hand constitutes clear indirect evidence of the spread of Phytophthora spp. from nurseries to plantings. This is particularly the case with afforestations of previous arable fields, meadows and pastures, where previous presence of typical tree pathogens like P. cambivora, P. cinnamomi and P. plurivora and host-specific pathogens such as $P . \times$ alni and $P$. quercina is highly unlikely. Further evidence comes from the comparison of infestation rates between forest plantings and seed-regenerated or mature forests. The analysis of the DSF database showed that P. cinnamomi is mainly found within planted oak forests in SW France, while being comparatively rare in seed-regenerated forests of the same region. Moreover, mean infestation rates found in planted young oak $(87.7 \%)$ and beech $(94.1 \%)$ stands $(80.7 \%)$ in this study were considerably higher than mean infestation rates of the 558 and 265 mature declining stands of oaks (62.4\%) and beech (81.5\%) examined across Europe in the last 20 years (Jung et al. 2013a). Also for C. sativa, the general Phytophthora infestation rate was clearly higher in 50 young forest plantings in this work (80.7\%) than in 35 mature forests (65.7\%) examined across Europe (Vettraino et al. 2005). If $P$. cinnamomi is considered alone, the difference between young plantings and mature forests is even higher (76\% versus $25.7 \%$ ). Finally, clear evidence for the importance of the nursery pathway was recently presented for the destructive diseases caused in the UK by the invasive exotic P. lateralis and P. austrocedrae on $C$. lawsoniana and Juniperus communis, respectively (Green et al. 2013, 2015).

Due to the high number and the random selection of forest nursery stands and forest plantations, the results presented here can be extrapolated to approximate the magnitude of Phytophthora-infested forest plantings at the European scale. 
Since the early 1990s, national subsidy programmes and several EU programmes, like EEC Regulation 2080/92, stimulated massive afforestations of agricultural and arable land, increasing the area of planted forests in Europe (excluding the Russian Federation) between 1990 and 2010 by 6 million hectares (Anonymous 2010, 2011a,b). If the mean infestation rate of forest nursery stands and forest plantings is $80 \%$, we can estimate an approximate total area of 4.8 million hectares of new forests potentially infested by Phytophthora planted in Europe over the last two decades. Given an average size of European afforestations of 7 hectares (http://ec.europa.eu/agriculture/envir/report/en/forest_en/report.htm), Phytophthora species were almost certainly inadvertantly spread to approximately 686000 new sites. In addition, between 1998 and 2007, 1.1 million hectares of harvested or burned mature forests were reforested per year by planting, totalling approximately 22 million hectares between 1990 and 2010, of which ca. 17.6 million hectares possibly were established with Phytophthora-infested nursery stock. Given the importance of plantations for European forestry, this informed estimate is of outstanding importance as the devastating impacts of this unprecedented large-scale spread of Phytophthora pathogens into the European forests and the implications for forestry and nature conservation are evident. In the EU afforestation programmes, broadleaved species represented $57 \%$ of the planted area, followed by conifers with $32 \%$, mixed stands with 7\% and fast-growing plantation trees with 4\% (Anonymous 2006), and proportions were similar in most national afforestation programmes. During the last twenty years, almost $50 \%$ of the afforestations in Europe were made in the Iberian peninsula, mainly by planting mixed or pure stands of $Q$. suber and Q. ilex (Barbero 2000). According to our data, $86 \%$ of these afforestations probably are infested by P. cinnamomi, a pathogen that represents a serious threat to the future of both oak species in the area.

Broadleaved tree species also have a dominant role in new silvicultural reforestation programmes, with the aim of replacing unnatural pure conifer plantations with mixed forests, in order to increase the stability of the ecosystems against predicted climatic change effects. There is a prominent example in Bavaria where 255000 hectares of spruce monocultures are being transformed to pure or mixed forests of $F$. sylvatica, 50000 hectares via planting of nursery stock (Ammer et al. 2005; http://baysf.de/de/home/unternehmen_wald/aktuelles/detailansicht/article/168/blatt-fuer-blatt.html). However, $89 \%$ of the Fagus stands tested in German nurseries in the present study were infested by at least one Phytophthora species involved in widespread decline and dieback of beech forests. Against a background of almost ubiquitous infestations of forest nursery stands and forest plantings of F. sylvatica, Quercus spp., C. sativa, Alnus spp. and many other forest tree species with aggressive invasive Phytophthora species that can cause large-scale dieback and mortality of mature forests of these tree species, the likely success and usefulness of the European afforestation and reforestation programmes must be seriously questioned. Continuous root and collar infections by Phytophthora spp. will not only lead to premature decline and mortality of a high proportion of the infested plantings as demonstrated by the present study. Once established in the planting sites, Phytophthora species will inevitably spread through zoospore production in soil water and with resting spores in soil particles adhering to animal hooves and paws, hikers' boots and tyres of vehicles, including logging machines and cars, to neighbouring forests and water courses. The impact of large-scale use of infested nursery stock on natural ecosystems was demonstrated previously by the devastating root and collar rot epidemic of Alnus spp. in Europe, caused by PAA, PAM and PAU (Streito et al. 2002; Gibbs et al. 2003; Jung and Blaschke 2004; Jung et al. 2013a).

On a global scale, the area of planted forests increased between 1990 and 2010 by 86 million hectares (Anonymous 2010, 2011a). The majority of this increase was in China where 50 million ha were afforested, and in North America where afforestation and reforestation activities comprised a total area of 18 million ha (Anonymous, 2011a). Although a series of surveys since the mid-1990s demonstrated high infestation rates of US ornamental nurseries with at least 31 Phytophthora species (MacDonald et al. 1994; Ferguson and Jeffers 1999; Lamour et al. 2003; Testa et al. 2005; Linderman and Davis 2006; Dart et al. 2007; Schwingle et al. 2007; Donahoo and Lamour 2008; Warfield et al. 2008; Goss et al. 2009; Yakabe et al. 2009; Hulvey et al. 2010; Olson and Benson 2011; Bienapfl and Balci 2014; Parke et al. 2014), the situation in forest nurseries is largely unknown. Also in China, Canada, Mexico and other countries with high rates of afforestation and reforestations, such as Australia, Brazil, Chile, India, Indonesia, Myanmar and Vietnam, no data on Phytophthora infestations of forest nurseries are available, and large-scale surveys are urgently required to assess the risk posed by the nursery pathway to the world's forests.

For plant biosecurity and disease management, it is of utmost importance to know which of the Phytophthora species and taxa detected in nurseries and plantings during this study are indigenous in Europe and which must be considered as alien invasive pathogens. Parameters commonly used as indirect indicators of the alien origin of a pathogen include consistent association with decline and dieback of common indigenous plant species or proven high aggressiveness to these plants in pathogenicity trials, occurrence in undisturbed natural ecosystems of other continents without associated disease, low genetic variability and close phylogenetic relatedness to other non-native species (Ko et al. 1978; Arentz and Simpson 1986; Oudemans and Coffey 1991; Erwin and Ribeiro 1996; Goodwin 1997; Dobrowolski et al. 2003; Cooke et al. 2005; Ivors et al. 2006; Rea et al. 2010, 2011; Ginetti et al. 2014). Based on cumulative, though indirect evidence, 59 of the 68 Phytophthora species detected in the nursery and planting surveys of the present work, 41 of the 49 Phytophthora taxa in $69 \%$ of nursery stands and 48 of the 56 Phytophthora taxa in 59\% of the plantings were probably introduced to Europe (Table 4).

The ITS Clade 6 species P. bilorbang, P. gonapodyides, P. lacustris, P. megasperma, P. taxon 'PgChlamydo' and P. taxon 'Forestsoil' are infrequently associated with diseases of forest trees and agricultural crops in Europe (Erwin and Ribeiro 1996; Jung et al. 1996, 2000, 2013a; Jung and Blaschke 2004; Jung 2009; Orlikowski et al. 2011; Nechwatal et al. 2013). However, they are common in healthy or undisturbed natural ecosystems in Europe, North America and Asia (Hansen and Delatour 1999; Reeser et al. 2011; Huai et al. 2013). Their origins, therefore, remain cryptic. These six taxa were found in $3.8 \%$ of the nursery stands and in $5.1 \%$ of the plantings. 
Table 4. Direct and indirect evidence for a non-European origin of 59 Phytophthora taxa present in nurseries and young plantings in Europe.

\begin{tabular}{|c|c|c|c|c|}
\hline $\begin{array}{l}\text { Phytophthora } \\
\text { Clade } \\
\text { (no. of } \\
\text { introduced taxa) }^{1}\end{array}$ & $\begin{array}{c}\text { Association with diseases } \\
\text { of and/or high aggressiveness } \\
\text { in pathogenicity trials to } \\
\text { common native European } \\
\text { tree, crop or } \\
\text { ornamental species }\end{array}$ & $\begin{array}{l}\text { Occurrence In healthy } \\
\text { undisturbed natural } \\
\text { ecosystems on } \\
\text { other continents }^{3}\end{array}$ & $\begin{array}{l}\text { Low genetic } \\
\text { variability of } \\
\text { European } \\
\text { populations }\end{array}$ & \\
\hline $1(8)$ & CAC, NIC, QUE, TEN & $\mathrm{NF}^{3}, \mathrm{NIC}^{6}, \mathrm{QUE}^{7}$ & INF, QUE & CAC, HED, NIC, PEL, QUE, TEN \\
\hline $2(12)$ & $\begin{array}{l}\text { ACE, CAP, CIP, CIT, } \\
\text { MUL, PIN, PLU, TRO }\end{array}$ & $\begin{array}{l}\text { CAP, CIP, CIT, PLU, } \\
\text { TRO, 'CEA' }{ }^{\prime} ; \text { MUL }^{9}\end{array}$ & ACE, PAC, PLU & CIP, PAC, 'CEA', 'CI' \\
\hline $3(0)$ & - & - & - & - \\
\hline $4(2)$ & QUT, PAL & $\mathrm{QUT}^{10}, \mathrm{PAL}^{11}$ & & QUT \\
\hline & - & & - & \\
\hline $6(12)$ & $\begin{array}{l}\text { ASP, HUM, INU, ROS, CHL, } \\
\text { 'GRE', 'HUM', 'ORG' }\end{array}$ & $\begin{array}{l}\text { ASP, CHL, GRE, INU, 'HUM'12; } \\
\text { CHL, GON, GRE, LAC }{ }^{13} \text {; } \\
\text { CHL, GON, LAC }{ }^{14}\end{array}$ & - & INU, 'GRE', HUM', 'ORG', 'RAS’ \\
\hline 7 (13) & $\begin{array}{l}\text { PAA, PAM, PAU, CAM, CIN, } \\
\text { FRA, MED, NIE, PAR, RUB, ULI }\end{array}$ & CIN, PAR $^{15} ;$ PAU $^{16}$ & CAM, CIN, PAU & $\begin{array}{l}\text { MED, NIE, PAA, } \\
\text { PAM, PAR, PAU, SOJ, 'SOJ' }\end{array}$ \\
\hline $8(13)$ & $\begin{array}{l}\text { AUS, CRY, DRE, POR, PRI, RAM, } \\
\text { SAN, SYR }\end{array}$ & $\mathrm{CRY}^{17} ; \mathrm{LAT}^{18}$ & AUS, RAM & \\
\hline $9(1)$ & POL & - & - & POL \\
\hline $10(1)$ & $\mathrm{R}$ & $\mathrm{KER}^{19}$ & - & - \\
\hline $\begin{array}{l}\text { No. of taxa } \\
(n=59)\end{array}$ & & 25 & 10 & 38 \\
\hline \multicolumn{5}{|c|}{ 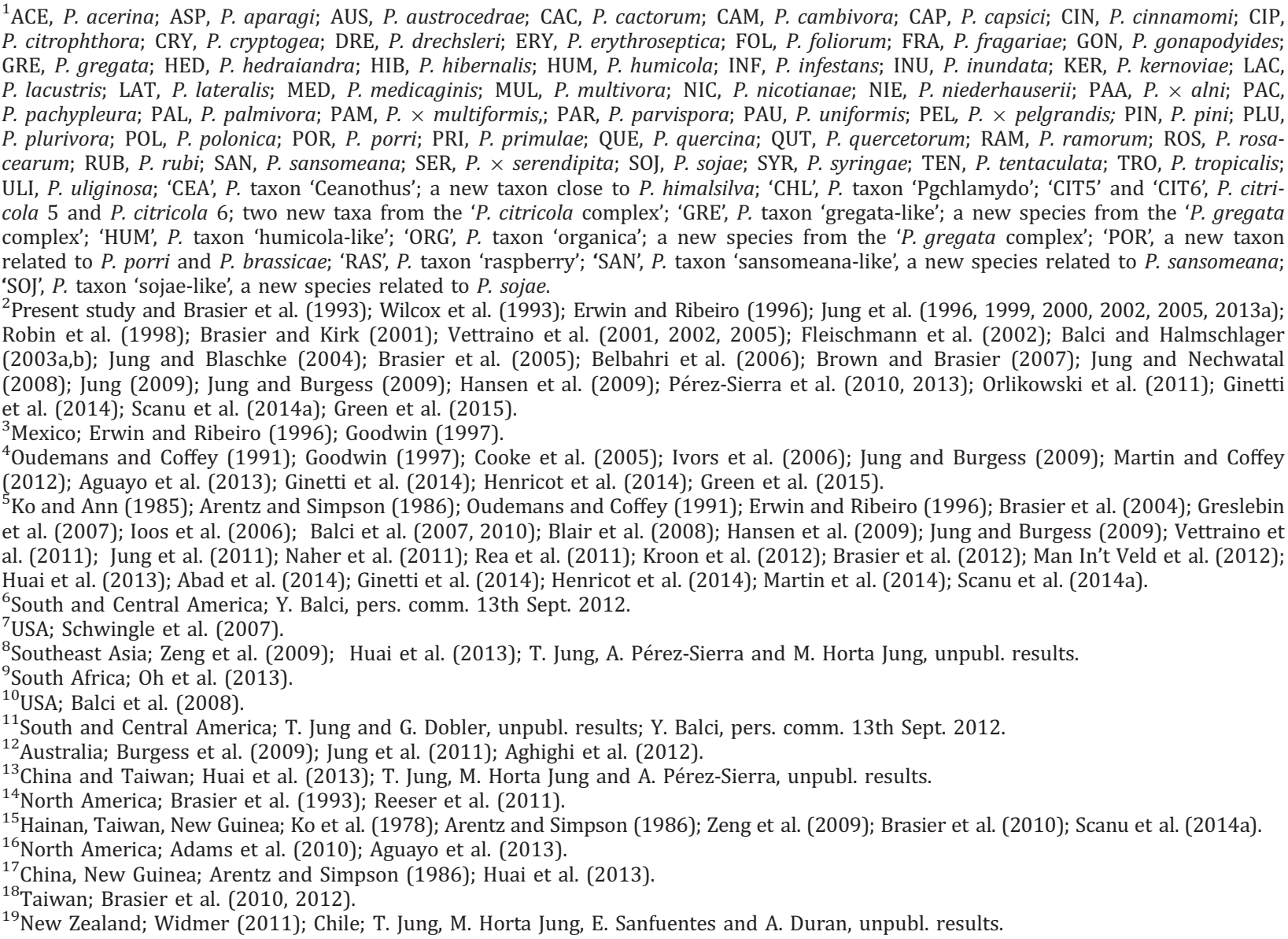 } \\
\hline
\end{tabular}

Due to scattered but widespread distribution in stands of F. sylvatica and Quercus spp. in Europe, inconsistent association with native diseased trees in highly favourable disease situations and relatively low aggressiveness in pathogenicity trials, P. pseudosyringae and P. psychrophila from ITS Clade 3 are most likely native to Europe (Jung et al. 1996, 2002, 2003, 2013a; Jung and Blaschke 2004; Jung 2009; Pérez-Sierra et al. 2013). The indigenous nature of P. pseudosyringae is also 
supported by the fact that European isolates have higher genetic variability than isolates from the USA where this pathogen is usually associated with bark cankers of oaks and tanoaks (Linzer et al. 2009). Being very closely related to P. pseudosyringae and P. psychrophila and occurring as a relatively mild leaf pathogen in natural stands of I. aquifolium in remote mountain forests in Sardinia and Corsica (Scanu et al. 2014b), P. ilicis is also most likely indigenous in Europe. Phytophthora ilicis, P. pseudosyringae and P. psychrophila were present in less than one per cent of the surveyed nursery stands and plantings.

During a survey of ornamental nurseries in Eastern Spain and the Baleares, Moralejo et al. (2009) detected 16 alien Phytophthora taxa also found in the present study and two other likely non-native taxa, P. kelmania from ITS Clade 9 and $P$. 'pseudo-citricola' from the 'P. citricola complex'. The number of described species and designated taxa of Phytophthora has increased dramatically over the last 20 years (Brasier 2009; Kroon et al. 2012), and 44 of the 64 Phytophthora taxa detected in the present study were unknown to science before 1990. Although no Phytophthora species has ever been intercepted during port inspections of plants-for-planting from another continent, it is beyond reasonable doubt that the intercontinental nursery trade is the major pathway for movement of Phytophthora species between continents as demonstrated for many fungal pathogens and insect pests (Erwin and Ribeiro 1996; Webber and Brasier 2005; Jones and Baker 2007; Brasier 2008; Grünwald et al. 2012; Liebhold et al. 2012; Hantula et al. 2013; Santini et al. 2013; Eschen et al. 2014). Almost 70\% of all insect pests and pathogens that established between 1860 and 2006 in the US were introduced with live plants (Liebhold et al. 2012). Similarly, the number of invasive forest pathogens (IFPs) in Europe has increased exponentially since 1800, and for $57 \%$ of the 123 established IFPs, the most likely pathway was trade in living plants (Santini et al. 2013). Apart from Phytophthora species, several bacterial and fungal pathogens that caused devastating epidemics of trees in Europe were introduced with living plants, including Erwinia amylovora causing fireblight of rosaceous trees, Ophiostoma ulmi and Ophiostoma novo-ulmi the causal agents of several waves of Dutch Elm Disease and, more recently, Hymenoscyphus fraxineus, causing ash dieback (Brasier 2008; Queloz et al. 2011; Santini et al. 2013; Baral et al. 2014). In the USA, annual plant imports increased between 1967 and 2010 by 500\% reaching 3.2 billion in 2007 (Liebhold et al. 2012). Similar trends and figures for Europe come from the recently completed EU-funded project ISEFOR (Increasing Sustainability of European Forests) during which import data from main ports of entry in the 10 countries Belgium, Cyprus, Czech Republic, Estonia, Finland, France, Italy, the Netherlands, Poland and Slovakia were analysed in detail. In 2010, in total 4.3 billion living plants were imported from overseas with the Netherlands accounting for almost $99 \%$ of all such imports. With 3.6 billion plants, Africa was the most important supplier, followed by Asia with 456 million plants, North and South America with 181 million and 81 million plants, respectively, and Oceania with 2.4 million plants. Between 2007 and 2010 , the volume of imported woody plants increased by $44 \%$, and in 2010, the proportion of woody plants reached 20.8\% of all imported plants (Ludovic Rigoux, Université Libre de Bruxelles, Belgium, pers. comm. 11 December. 2012). The volume of imported plants has long surpassed the port inspection capacities by several orders of magnitude. In the USA, only $2 \%$ of imported nursery stock is inspected by APHIS (Brasier 2008). Considering the fact that in the EU, no more than $3 \%$ of the imported consignments are subject to phytosanitary inspections (unpublished results, EU COST Action FP 1002 'Pathway Evaluation and Pest Risk Management In Transport [PERMIT]'), such enormous numbers of living plants provide ample opportunities for the unintentional introduction of pests and pathogens, in particular Phytophthora spp., travelling as passive hitchhikers in roots and adhering soil particles of both host and non-host plants (Brasier 2008; Pérez-Sierra and Jung 2013). This problem is of particular concern against the background of an estimated number of between 150 and 500 unknown Phytophthora species living unnoticed in a balanced equilibrium with co-evolved host plants in their natural habitats (Brasier 2009).

Fundamental changes in the international plant distribution chain, for example increased complexity; increasingly blurred roles and distinctions of companies trading in and transporting plants; specialization of companies resulting in the flow of individual plants through several nurseries; favourable climate and low costs for producing plants overseas; more efficient and rapid transport systems, packaging and shipping technologies; e-commerce; and changed consumer demands, in particular the demand for novel and exotic plants and 'instant landscapes', are factors responsible for the exponential increase in the international trade in plants-for-planting and have extended the range of plant origin, availability and viability (Brasier 2008; Dehnen-Schmutz et al. 2010; Drew et al. 2010; Liebhold et al. 2012). The dimension of the threat posed by invasive pathogens has spurred research projects like ISEFOR (2011-2014) and FORTHREATS (European network on emerging diseases and invasive species threats to European Forest Ecosystems; 2007-2009), mentioned above, the establishment of several European COST Actions, such as FP 0801 'Established and Emerging Phytophthora: Increasing Threats to Woodland and Forest Ecosystems in Europe', FP 1002 (PERMIT), FP1103 'Fraxinus dieback in Europe: elaborating guidelines and strategies for sustainable management (FRAXBACK)' and FP 1401 'A global network of nurseries as early warning system against alien tree pests (Global Warning)', and the IUFRO (International Union of Forest Research Organizations) units 7.02.09 'Phytophthora in Forests and Natural Ecosystems' and 7.03.12 'Alien Invasive Species and International Trade'. All projects and networks have clearly stated that current international plant health protocols based on random visual inspections for symptoms of listed quarantine organisms (Schrader and Unger 2003) have failed and must be considered as outdated and seriously flawed. This conclusion is confirmed by the compelling evidence presented in this paper. The almost ubiquitous infestations of nurseries and plantings across Europe and the facts that none of the 59 putatively exotic Phytophthora taxa detected in the present study had been intercepted at the ports of entry and that the spread of the quarantine organism $P$. ramorum was not halted despite strict quarantine regulations demonstrate failures of plant biosecurity in Europe. Most of the ca. 150 currently known species and designated taxa of Phytophthora were unknown to science before they turned up in other continents as invasive aggressive pathogens of native plants or plantation crops (Erwin and Ribeiro 1996; Brasier 2008; 
Hansen 2008; Hansen et al. 2012; Jung et al. 2013a). Eradication or containment of introduced Phytophthora species in the wider environment is impossible because of the highly successful survival strategies of these organisms, the lack of suitable registered biocides and insufficient allocation of human and financial resources to plant biosecurity. Therefore, the prevention of further introductions of unknown, potentially invasive Phytophthora spp. and other pathogens must be given highest priority in plant biosecurity. In this context, article VI.2 of the International Plant Protection Convention (IPPC) that prohibits phytosanitary measures against unregulated pests appears to be paradoxical since in the current system regulations can only be implemented following a pest risk assessment which in turn implies that the pathogen has to be known (Schrader and Unger 2003; Brasier 2008). A solution to this dilemma is the adoption of a pathway regulation approach based on pathway risk analyses, and risk-based inspection regimes performed by an adequate number of skilled staff using molecular high-throughput detection tools. These protocols are recommended at the ports of entry and in nurseries to minimize the risks of further introductions and dissemination of both known and, even more importantly, unknown potential pathogens to Europe. Such an approach would follow the lead of the strict quarantine system in Australia which has proven bioeconomic benefits (Keller et al. 2007).

Best management practices for reducing the risk of introduction and dispersal of Phytophthora spp. in nurseries were recently presented in the comprehensive review of Parke and Grünwald (2012) and will not be discussed in detail here.

In conclusion, it is abundantly clear that the ubiquitous Phytophthora infestations of nursery stock represent a serious threat to tree health and ecosystem stability on a European scale and that the current phytosanitary system will allow further introductions of potentially invasive Phytophthora pathogens to Europe and other continents with subsequent dissemination via the nursery trade. Instead of small corrections to an outdated and poorly performing system, a new holistic and integrated systems approach is urgently required, which must encompass (i) a major change in the phytosanitary system from a host-by-host and pest-by-pest approach to a pathway regulation approach with high-frequency inspections of high-risk consignments using molecular high-throughput detection methods (e.g. Scibetta et al. 2012), and (ii) due to failure of self-regulation in the industry an international certification system and a mandatory hygiene code for the production and trading of non-infested nursery stock. The overdue improvements to regulation of the nursery industry must consider the complexities in the nursery trade and address all agents involved. As even partial code compliance can result in complete failure to prevent introduction and spread of invasive Phytophthora species, regular controls of compliance and rigorous enforcement of regulations will be necessary. In addition, public information campaigns to develop consumer awareness of the importance of invasive pathogens will be helpful as public attention would be a strong incentive for the nursery industry to build up a positive reputation by distributing only clean stock (Drew et al. 2010).

\section{Acknowledgements}

The authors are grateful to all public and private owners of nurseries and plantings who contributed to this extensive study. T. Jung acknowledges the support by the Regione Autonoma della Sardegna, Visiting Professor Program at the University of Sassari, Italy. The authors also thank the COST Office and the European Council for providing the European COST Actions FP0801 (http://www.cost.eu/domains_actions/fps/Actions/FP0801) and FP 1002 (http://www.cost.eu/domains_actions/fps/Actions/FP1002), the EU projects FORTHREATS and ISEFOR, and BiodivERsA project RESIPATH as platforms for stimulating discussions on the nursery pathway and possible management solutions.

\section{References}

Abad, Z. G.; Abad, J. A.; Cacciola, S. A.; Pane, A.; Faedda, R.; Moralejo, E.; Pérez-Sierra, A.; Abad-Campos, P.; Alvarez-Bernaola, L. A.; Bakonyi, J.; Jòzsa, A.; Herrero, M. L.; Burgess, T. I.; Cunnington, J. A.; Smith, I. W.; Balci, Y.; Blomquist, C.; Henricot, C.; Denton, G.; Spies, C.; Mcleod, A.; Belbahri, L.; Cooke, D.; Kageyama, K.; Uematsu, S.; Kurbetli, I.; Değirmenci, K., 2014: Phytophthora niederhauserii sp. nov., a polyphagous species associated with ornamentals, fruit trees and native plants in 13 countries. Mycologia 106, 431-447.

Adams, G. C.; Catal, M.; Trummer, L., 2010: Distribution and severity of alder Phytophthora in Alaska. In: Proceedings of the Sudden Oak Death Fourth Science Symposium. Ed. by Frankel, S. J.; Kliejunas, T.; Palmieri, K. M. Albany, CA, USA: Forest Service, USDA: Gen. Tech. Rep. PSW-GTR-229: pp. 29-49.

Aghighi, S.; Hardy, G. E. S. J.; Scott, J.; Burgess, T. I., 2012: Phytophthora bilorbang sp. nov., a new species associated with the decline of Rubus anglocandicans (European blackberry) in Western Australia. Eur. J. Plant Pathol. 133, 841-855.

Aguayo, J.; Adams, G. C.; Halkett, F.; Catal, M.; Husson, C.; Nagy, Z. Á.; Hansen, E. M.; Marçais, B.; Frey, P., 2013: Strong genetic differentiation between North American and European populations of Phytophthora alni subsp. uniformis. Phytopathology 103, $190-199$.

Ammer, C.; Albrecht, L.; Borchert, H.; Brosinger, F.; Dittmar, C.; Elling, W.; Ewald, J.; Felbermeier, B.; von Gilsa, H.; Huss, J.; Kenk, G.; Kölling, C.; Kohnle, U.; Meyer, P.; Mosandl, R.; Moosmayer, H. U.; Palmer, S.; Reif, A.; Rehfuess, K. E.; Stimm, B., 2005: Zur Zukunft der Buche (Fagus sylvatica L.) in Mitteleuropa. Allg. Forst- u. J. Ztg. 176, 60-67.

Anonymous, 2006: Proceedings of the 'Workshop on pan-European recommendations for afforestation and reforestation in the context of UNFCCC.' Warsaw, Poland: MCPFE Liaison Unit Warsaw, 46 pp.

Anonymous, 2010: Global forest resources assessment 2010. FAO Forestry Paper 163, 340 pp.

Anonymous, 2011a: State of the world' s forests 2011. Rome, Italy: Food and Agriculture Organization of the United Nations, p. 164.

Anonymous, 2011b: State of Europe' s forests 2011: Status and trends in sustainable forest management in Europe. Ministerial Conference on the Protection of Forests in Europe. Aas, Norway: FOREST EUROPE Liaison Unit Oslo, 307 pp.

Arentz, F.; Simpson, J. A., 1986: Distribution of Phytophthora cinnamomi in Papua New Guinea and notes on its origin. Trans. Br. Mycol. Soc. 87, 289-295.

Balci, Y.; Halmschlager, E., 2003a: Incidence of Phytophthora species in oak forests in Austria and their possible involvement in oak decline. Forest Pathol. 33, 157-174. 
Balci, Y.; Halmschlager, E., 2003b: Phytophthora species in oak ecosystems in Turkey and their association with declining oak trees. Plant. Pathol. 52, 694-702.

Balci, Y.; Balci, S.; Eggers, J.; MacDonald, W. L.; Juzwik, J.; Long, R. P.; Gottschalk, K. W., 2007: Phytophthora spp. associated with forest soils in eastern and north-central U.S. oak ecosystems. Plant Dis. 91, 705-710.

Balci, Y.; Balci, S.; Blair, J. E.; Park, S. Y.; Kang, S.; Macdonald, W. L., 2008: Phytophthora quercetorum sp. nov., a novel species isolated from eastern and northcentral USA oak forest soils. Mycol. Res. 112, 906-916.

Balci, Y.; Long, R. P.; Mansfield, M.; Balser, D.; MacDonald, W. L., 2010: Involvement of Phytophthora species in white oak (Quercus alba) decline in southern Ohio. Forest Pathol. 40, 430-442.

Baral, H.-O.; Queloz, V.; Hosoya, T., 2014: Hymenoscyphus fraxineus, the correct scientific name for the fungus causing ash dieback in Europe. IMA Fungus 5, 79-80.

Barbero, A., 2000: Afforestation in Spain - stocktaking report after the regionalization. In: NEWFOR - New forests for Europe: afforestation at the turn of the century. Ed. by Weber, N. Joensuu, Finland: European Forest Institute. EFI Procedings No. 35, pp. 67-76.

Belbahri, L.; Moralejo, E.; Calmin, G.; Oszako, T.; Garcia, J. A.; Descals, E.; Lefort, F., 2006: Phytophthora polonica, a new species isolated from declining Alnus glutinosa stands in Poland. FEMS Microbiol. Lett. 261, 165-174.

Bienapfl, J. C.; Balci, Y., 2014: Movement of Phytophthora spp. in Maryland' s nursery trade. Plant Dis. 98, 134-144.

Blair, J. E.; Coffey, M. D.; Park, S. Y.; Geiser, D. M.; Kang, S., 2008: A multi-locus phylogeny for Phytophthora utilizing markers derived from complete genome sequences. Fungal Genet. Biol. 45, 266-277.

Brasier, C. M., 2008: The biosecurity threat to the UK and global environment from international trade in plants. Plant. Pathol. 57, 792808.

Brasier, C., 2009: Phytophthora biodiversity: How many Phytophthora species are there. In: Phytophthoras in forests and natural ecosystems. Proceedings of the 4th IUFRO Working Party S07.02.09 Meeting. Ed. by Goheen, E. M.; Frankel, S. J. Albany, CA: USDA Forest Service, Pacific Southwest Research Station, Gen. Tech. Rep. PSW-GTR-221: pp. 101-115.

Brasier, C. M.; Kirk, S. A., 2001: Comparative aggressiveness of standard and variant hybrid alder phytophthoras, Phytophthora cambivora and other Phytophthora species on bark of Alnus, Quercus and other woody hosts. Plant. Pathol. 50, 218-229.

Brasier, C.; Webber, J., 2010: Sudden larch death. Nature 466, 824-825.

Brasier, C. M.; Robredo, F.; Ferraz, J. F. P., 1993: Evidence for Phytophthora cinnamomi involvement in Iberian oak decline. Plant. Pathol. 42, 140-145.

Brasier, C. M.; Cooke, D. E. L.; Duncan, J. M.; Hansen, E. M., 2003a: Multiple new phenotypic taxa from trees and riparian ecosystems in Phytophthora gonapodyides-P. megasperma ITS Clade 6, which tend to be high-temperature tolerant and either inbreeding or sterile. Mycol. Res. 107, 277-290.

Brasier, C. M.; Sánchez-Hernández, E.; Kirk, S. A., 2003b: Phytophthora inundata sp. nov., a part heterothallic pathogen of trees and shrubs in wet or flooded soils. Mycol. Res. 107, 477-484.

Brasier, C. M.; Kirk, S. A.; Delcan, J.; Cooke, D. E. L.; Jung, T.; Man in't Veld, W. A., 2004: Phytophthora alni sp. nov. and its variants: designation of emerging heteroploid hybrid pathogens spreading on Alnus trees. Mycol. Res. 108, 1172-1184.

Brasier, C. M.; Beales, P. A.; Kirk, S. A.; Denman, S.; Rose, J., 2005: Phytophthora kernoviae sp. nov. an invasive pathogen causing bleeding stem lesions on forest trees and foliar necrosis of ornamentals in Britain. Mycol. Res. 109, 853-859.

Brasier, C. M.; Vettraino, A. M.; Chang, T. T.; Vannini, A., 2010: Phytophthora lateralis discovered in an old growth Chamaecyparis forest in Taiwan. Plant. Pathol. 59, 595-603.

Brasier, C. M.; Franceschini, S.; Vettraino, A. M.; Hansen, E. M.; Green, S.; Robin, C.; Webber, J. F.; Vannini, A., 2012: Four phenotypically and phylogenetically distinct lineages in Phytophthora lateralis. Fungal Biol. 116, 1232-1249.

Brown, A. V.; Brasier, C. M., 2007: Colonization of tree xylem by Phytophthora ramorum, P. kernoviae and other Phytophthora species. Plant. Pathol. 56, 227-241.

Burgess, T. I.; Webster, J. L.; Ciampini, J. A.; White, D.; Hardy, G. E. S. J.; Stukely, M. J. C., 2009: Re-evaluation of Phytophthora species isolated during 30 years of vegetation health surveys in Western Australia using molecular techniques. Plant Dis. 93, 215-223.

Cooke, D. E. L.; Drenth, A.; Duncan, J. M.; Wagels, G.; Brasier, C. M., 2000: A molecular phylogeny of Phytophthora and related oomycetes. Fungal Genet. Biol. 30, 17-32.

Cooke, D. E. L.; Jung, T.; Williams, N. A.; Schubert, R.; Oßwald, W.; Duncan, J., 2005: Genetic diversity of European populations of the oak fine-root pathogen Phytophthora quercina. Forest Pathol. 35, 1-14.

Cullen, D. W.; Lees, A. K.; Toth, I. K.; Duncan, J. M., 2001: Conventional PCR and real-time quantitative PCR detection of Helminthosporium solani in soil and on potato tubers. Eur. J. Plant Pathol. 107, 387-398.

Dart, N. L.; Chastagner, G. A.; Rugarber, E. F.; Riley, K. L., 2007: Recovery frequency of Phytophthora ramorum and other Phytophthora spp. in the soil profile of ornamental retail nurseries. Plant Dis. 91, 1419-1422.

Davison, E. M.; Drenth, A.; Kumar, S.; Mack, S.; Mackie, A. E.; McKirdy, S., 2006: Pathogens associated with nursery plants imported into Western Australia. Australas. Plant Pathol. 35, 473-475.

Dehnen-Schmutz, K.; Holdenrieder, O.; Jeger, M. J.; Pautasso, M., 2010: Structural change in the international horticultural industry: some implications for plant health. Sci. Hortic-Amsterdam 125, 1-15.

Dobrowolski, M. P.; Tommerup, I. C.; Blakeman, H. D., 2003: Non-mendelian inheritance revealed in a genetic analysis of sexual progeny of Phytophthora cinnamomi with microsatellite markers. Fungal Genet. Biol. 35, 197-212.

Donahoo, R. S.; Lamour, K. H., 2008: Characterization of Phytophthora species from leaves of nursery woody ornamentals in Tennessee. HortScience 43, 1833-1837.

Drew, J.; Anderson, N.; Andow, D., 2010: Conundrums of a complex vector for invasive species control: a detailed examination of the horticultural industry. Biol. Invasions 12, 2837-2851.

Erwin, D. C.; Ribeiro, O. K., 1996: Phytophthora Diseases Worldwide. St. Paul, Minnesota: APS Press, American Phytopathological Society, $562 \mathrm{pp}$.

Eschen, R.; Holmes, T.; Smith, D.; Roques, A.; Santini, A.; Kenis, M., 2014: Likelihood of establishment of tree pests and diseases based on their worldwide occurrence as determined by hierarchical cluster analysis. Forest Ecol. Manag. 315, 103-111.

Ferguson, A. J.; Jeffers, S. N., 1999: Detecting multiple species of Phytophthora in container mixes from ornamental crop nurseries. Plant Dis. 83, 1129-1136.

Fleischmann, F.; Schneider, D.; Matyssek, R.; Oßwald, W. F., 2002: Investigations on Net CO2 assimilation, transpiration and root growth of Fagus sylvatica infested with four different Phytophthora species. Plant Biol. 4, 144-152.

Gallego, F. J.; Perez de Algaba, A.; Fernandez-Escobar, R., 1999: Etiology of oak decline in Spain. Eur. J. For. Path. $29,17-27$.

Gibbs, J. N.; Van Dijk, C.; Webber, J. F., eds, 2003: Phytophthora disease of alder in Europe. Farnham, UK: Forest Research Station. Forestry Commission Bulletin 126, 82 pp. 
Ginetti, B.; Moricca, S.; Squires, J. N.; Cooke, D. E. L.; Ragazzi, A.; Jung, T., 2014: Phytophthora acerina sp. nov., a new species causing bleeding cankers and dieback of Acer pseudoplatanus trees in planted forests in Northern Italy. Plant. Pathol. 63, 858-876.

Goodwin, S. B., 1997: The population genetics of Phytophthora. Phytopathology 87, 462-473.

Goss, E. M.; Larsen, M.; Chastagner, G. A.; Givens, D. R.; Grünwald, N. J., 2009: Population genetic analysis infers migration pathways of Phytophthora ramorum in US nurseries. PLoS Pathog. 5, e1000583.

Green, S.; Brasier, C. M.; Schlenzig, A.; McCracken, A.; MacAskill, G. A.; Wilson, M.; Webber, J. F., 2013: The destructive invasive pathogen Phytophthora lateralis found on Chamaecyparis lawsoniana across the UK. Forest Pathol. 43, 19-28.

Green, S.; Elliot, M.; Armstrong, A.; Hendry, S. J., 2015: Phytophthora austrocedrae emerges as a serious threat to juniper (Juniperus communis) in Britain. Plant. Pathol. 64, 456-466.

Greslebin, A.; Hansen, E. M.; Sutton, W., 2007: Phytophthora austrocedrae sp. nov., a new species associated with Austrocedrus chilensis mortality in Patagonia (Argentina). Mycol. Res. 111, 308-316.

Grünwald, N. J.; Garbelotto, M.; Goss, E. M.; Heungens, K.; Prospero, S., 2012: Emergence of the sudden oak death pathogen Phytophthora ramorum. Trends Microbiol. 20, 131-138.

Hansen, E. M., 2008: Alien forest pathogens: Phytophthora species are changing world forests. Boreal Environ. Res. 13, 33-41.

Hansen, E.; Delatour, C., 1999: Phytophthora species in oak forests of north-east France. Ann. For. Sci. 56, 539-547.

Hansen, E. M.; Goheen, D. J.; Jules, E. S.; Ullian, B., 2000: Managing Port-Orford-Cedar and the introduced pathogen Phytophthora lateralis. Plant Dis. 84, 4-14.

Hansen, E. M.; Wilcox, W. F.; Reeser, P. W.; Sutton, W., 2009: Phytophthora rosacearum and P. sansomeana, new species segregated from the Phytophthora megasperma "complex". Mycologia 101, 129-135.

Hansen, E. M.; Reeser, P. W.; Sutton, W., 2012: Phytophthora beyond agriculture. Annu. Rev. Phytopathol. 50, 359-378.

Hantula, J.; Müller, M.; Uusivuori, J., 2013: International plant trade associated risks: laissezfaire or novel solutions. Environ. Sci. Policy 37, $158-160$.

Hardy, G. E.; Sivasithamparam, K., 1988: Phytophthora spp. associated with container-grown plants in nurseries in Western Australia. Plant Dis. 72, 435-437.

Henricot, B.; Pérez-Sierra, A.; Jung, T., 2014: Phytophthora pachypleura sp. nov., a new species causing root rot of Aucuba japonica and other ornamentals in the United Kingdom. Plant. Pathol. 63, 1095-1109.

Hong, C.; Gallegly, M. E.; Richardson, P. A.; Kong, P., 2011: Phytophthora pini Leonian resurrected to distinct species status. Mycologia 103, 351-360.

Huai, W. X.; Tian, G.; Hansen, E. M.; Zhao, W. X.; Goheen, E. M.; Grünwald, N. J.; Cheng, C., 2013: Identification of Phytophthora species baited and isolated from forest soil and streams in northwestern Yunnan province, China. Forest Pathol. 43, 87-103.

Hulvey, J.; Gobena, D.; Finley, L.; Lamour, K. H., 2010: Co-occurrence and genotypic distribution of Phytophthora species recovered from watersheds and plant nurseries of eastern Tennessee. Mycologia 102, 1127-1133.

Husson, C.; Aguayo, J.; Revellin, C.; Frey, P.; Ioos, R.; Marçais, B., 2015: Evidence for homoploid speciation in Phytophthora alni supports taxonomic reclassification in this species complex. Fungal Genet. Biol. 77, 12-21.

Ioos, R.; Andrieux, A.; Marçais, B.; Frey, P., 2006: Genetic characterization of the natural hybrid species Phytophthora alni as inferred from nuclear and mitochondrial DNA analyses. Fungal Genet. Biol. 43, 511-529.

Ivors, K.; Garbelotto, M.; Vries, I. D. E.; Ruyter-Spira, C.; Hekkert, B. T. E.; Rosenzweig, N.; Bonants, P., 2006: Microsatellite markers identify three lineages of Phytophthora ramorum in US nurseries, yet single lineages in US forest and European nursery populations. Mol. Ecol. 15, 1493-1505.

Jeffers, S. N.; Martin, S. B., 1986: Comparison of two media selective for Phytophthora and Pythium species. Plant Dis. 70, $1038-1043$.

Jones, D. R.; Baker, R. H. A., 2007: Introductions of non-native plant pathogens into Great Britain 1970-2004. Plant. Pathol. 56, 891-910.

Jönsson, U.; Jung, T.; Sonesson, K.; Rosengren, U., 2005: Relationships between health of Quercus robur, occurrence of Phytophthora species and site conditions in southern Sweden. Plant. Pathol. 54, 502-511.

Jules, E. S.; Kauffman, M. J.; Ritts, W. D.; Carroll, A. L., 2002: Spread of an invasive pathogen over a variable landscape: a non native root rot on Port-Orford-cedar. Ecology 83, 3167-3181.

Jung, T., 2009: Beech decline in Central Europe driven by the interaction between Phytophthora infections and climatic extremes. Forest Pathol. 39, 73-94.

Jung, T.; Blaschke, H., 1996: Phytophthora root rot in declining forest trees. Phyton (Austria) 36, 95-102.

Jung, T.; Blaschke, M., 2004: Phytophthora root and collar rot of alders in Bavaria: distribution, modes of spread and possible management strategies. Plant. Pathol. 53, 197-208.

Jung, T.; Burgess, T. I., 2009: Re-evaluation of Phytophthora citricola isolates from multiple woody hosts in Europe and North America reveals a new species, Phytophthora plurivora sp. nov. Persoonia 22, 95-110.

Jung, T.; Dobler, G., 2002: First report of littleleaf disease caused by Phytophthora cinnamomi on Pinus occidentalis in the Dominican Republic. Plant Dis. 86, 1275.

Jung, T.; Nechwatal, J., 2008: Phytophthora gallica sp. nov., a new species from rhizosphere soil of declining oak and reed stands in France and Germany. Mycol. Res. 112, 1195-1205.

Jung, T.; Blaschke, H.; Neumann, P., 1996: Isolation, identification and pathogenicity of Phytophthora species from declining oak stands. Eur. J. For. Path. 26, 253-272.

Jung, T.; Cooke, D. E. L.; Blaschke, H.; Duncan, J. M.; Osswald, W., 1999: Phytophthora quercina sp. nov., causing root rot of European oaks. Mycol. Res. 103, 785-798.

Jung, T.; Blaschke, H.; Osswald, W., 2000: Involvement of soilborne Phytophthora species in Central European oak decline and the effect of site factors on the disease. Plant. Pathol. 49, 706-718.

Jung, T.; Hansen, E. M.; Winton, L.; Oßwald, W.; Delatour, C., 2002: Three new species of Phytophthora from European oak forests. Mycol. Res. 106, 397-411.

Jung, T.; Nechwatal, J.; Cooke, D. E. L.; Hartmann, G.; Blaschke, M.; Oßwald, W. F.; Duncan, J. M.; Delatour, C., 2003: Phytophthora pseudosyringae sp. nov., a new species causing root and collar rot of deciduous tree species in Europe. Mycol. Res. 107, 772-789.

Jung, T.; Hudler, G. W.; Jensen-Tracy, S. L.; Griffiths, H. M.; Fleischmann, F.; Oßwald, W., 2005: Involvement of Phytophthora spp. in the decline of European beech in Europe and the USA. Mycologist 19, 159-166.

Jung, T.; Stukely, M. J. C.; Hardy, G. E.; St, J.; White, D.; Paap, T.; Dunstan, W. A.; Burgess, T. I., 2011: Multiple new Phytophthora species from ITS Clade 6 associated with natural ecosystems in Australia: evolutionary and ecological implications. Persoonia 26, 13-39.

Jung, T.; Vettraino, A. M.; Cech, T. L.; Vannini, A., 2013a: The impact of invasive Phytophthora species on European forests. In: Phytophthora: A global perspective. Ed. by Lamour, K. Wallingford, UK: CABI, pp. 146-158. 
Jung, T.; Colquhoun, I. J.; Hardy, G. E. S. J., 2013b: New insights into the survival strategy of the invasive soilborne pathogen Phytophthora cinnamomi in different natural ecosystems in Western Australia. Forest Pathol. 43, 266-288.

Keller, R. P.; Lodge, D. M.; Finnoff, D. C., 2007: Risk assessment for invasive species produces net bioeconomic benefits. Proc. Natl Acad. Sci. USA 104, 203-207.

Ko, W. H.; Ann, P. J., 1985: Phytophthora humicola, a new species from soil of a citrus orchard in Taiwan. Mycologia 77, 631-636.

Ko, W. H.; Chang, H. S.; Su, H. J., 1978: Isolates of Phytophthora cinnamomi from Taiwan as evidence for an Asian origin of the species. Trans. Br. Mycol. Soc. 71, 496-499.

Kroon, L. P.; Brouwer, H.; de Cock, A. W.; Govers, F., 2012: The genus Phytophthora anno 2012. Phytopathology 102, $348-364$.

Lamour, K. H.; Daughtrey, M. L.; Benson, D. M.; Hwang, J.; Hausbeck, M. K., 2003: Etiology of Phytophthora drechsleri and P. nicotianae $(=$. parasitica $)$ diseases affecting floriculture crops. Plant Dis. 87, 854-858.

Liebhold, A. M.; Brockerhoff, E. G.; Garrett, L. J.; Parke, J. L.; Britton, K. O., 2012: Live plant imports: the major pathway for forest insect and pathogen invasions of the US. Front. Ecol. Environ. 10, 135-143.

Lilja, A.; Rikala, R.; Hietala, A.; Heinonen, R., 1996: Stem lesions on Betula pendula seedlings in Finnish forest nurseries and the pathogenicity of Phytophthora cactorum. Eur. J. For. Path. 26, 89-96.

Linderman, R. G.; Davis, E. A., 2006: Survival of Phytophthora ramorum compared to other Phytophthora in potting media components, compost, and soil. Horttechnology 16, 502-507.

Linzer, R. E.; Rizzo, D. M.; Cacciola, S. O.; Garbelotto, M., 2009: AFLPs detect low genetic diversity for Phytophthora nemorosa and P. pseudosyringae in the US and Europe. Mycol. Res. 113, 298-307.

MacDonald, J. D.; Ali-Shtayeh, M. S.; Kabashima, J.; Stites, J., 1994: Occurrence of Phytophthora species in recirculated nursery irrigation effluents. Plant Dis. 78, 607-611.

Man In't Veld, W. A.; Rosendahl, K. C. H. M.; Hong, C., 2012: Phytophthora x serendipita and Phytophthora x pelgrandis, two destructive pathogens generated by natural hybridization. Mycologia 104, 1390-1396.

Marçais, B.; Bergot, M.; Pérarnaud, V.; Levy, A.; Desprez-Loustau, M. L., 2004: Prediction and mapping of the impact of winter temperatures on the development of Phytophthora cinnamomi induced cankers on red and pedunculate oak. Phytopathology 94, 826-831.

Martin, F. N.; Blair, J. E.; Coffey, M. D., 2014: A combined mitochondrial and nuclear multilocus phylogeny of the genus Phytophthora. Fungal Genet. Biol. 66, 19-32.

Martin, F. N.; Coffey, M. D., 2012: Mitochondrial haplotype analysis for differentiation of isolates of Phytophthora cinnamomi. Phytopathology 102, 229-239.

Masago, H.; Yoshikawa, M.; Fukada, M.; Nakanishi, N., 1977: Selective inhibition of Pythium spp. on a medium for direct isolation of Phytophthora spp. from soils and plants. Phytopathology 67, 425-428.

Migliorini, D.; Ghelardini, L.; Tondine, E.; Luchi, N.; Santini, A., 2015: The potential of symptomless potted plants for carrying invasive soilborne plant pathogens. Diversity Distrib. 2015, 1-12.

Moralejo, E.; Pérez-Sierra, A.; Álvarez, L. A.; Belbahri, L.; Lefort, F.; Descals, E., 2009: Multiple alien Phytophthora taxa discovered on diseased ornamental plants in Spain. Plant. Pathol. 58, 100-110.

Naher, M.; Motohash, K.; Watanabe, H.; Chikuo, Y.; Senda, M.; Suga, H.; Kageyama, K., 2011: Phytophthora chrysanthemi sp. nov., a new species causing root rot of chrysanthemum in Japan. Mycol. Prog. 10, 21-31.

Nechwatal, J.; Bakonyi, J.; Cacciola, S. O.; Cooke, D. E. L.; Jung, T.; Nagy, Z. A.; Vannini, A.; Vettraino, A. M.; Brasier, C. M., 2013: The morphology, behaviour and molecular phylogeny of Phytophthora taxon Salixsoil and its redesignation as Phytophthora lacustris sp. nov. Plant. Pathol. 62, 355-369.

Oak, S. W.; Tainter, F. H., 1988: Risk prediction of loblolly pine decline on littleleaf disease sites in South Carolina. Plant Dis. 72, $289-293$.

Oh, E.; Gryzenhout, M.; Wingfield, B. D.; Wingfield, M. J.; Burgess, T. I., 2013: Surveys of soil and water reveal a goldmine of Phytophthora diversity in South African natural ecosystems. IMA Fungus 4(1), 123-131.

Olson, H. A.; Benson, D. M., 2011: Characterization of Phytophthora spp. on floriculture crops in North Carolina. Plant Dis. 95, 1013-1020.

Orlikowski, L. B.; Duda, B.; Szkuta, G., 2004: Phytophthora citricola on European beech and Silver fir in Polish forest nurseries. J. Plant Prot. Res. 44, 57-64.

Orlikowski, L. B.; Ptaszek, M.; Rodziewicz, A.; Nechwatal, J.; Thinggaard, K.; Jung, T., 2011: Phytophthora root and collar rot of mature Fraxinus excelsior in forest stands in Poland and Denmark. Forest Pathol. 41, 510-519.

Oudemans, P.; Coffey, M. D., 1991: Isozyme comparison within and among worldwide sources of three morphologically distinct species of Phytophthora. Mycol. Res. 95, 19-30.

Parke, J. L.; Grünwald, N. J., 2012: A systems approach for management of pests and pathogens of nursery crops. Plant Dis. 96, 1236-1244.

Parke, J. L.; Knaus, B. J.; Fieland, V. J.; Lewis, C.; Grünwald, N. J., 2014: Phytophthora community structure analyses in Oregon nurseries inform systems approaches to disease management. Phytopathology 104, 1052-1062.

Pautasso, M.; Dehnen-Schmutz, K.; Holdenrieder, O.; Pietravalle, S.; Salama, N.; Jeger, M. J.; Lange, E.; Hehl-Lange, S., 2010: Plant health and global change - some implications for landscape management. Biol. Rev. 85, 729-755.

Pérez-Sierra, A.; Jung, T., 2013: Phytophthora in woody ornamental nurseries. In: Phytophthora: A global perspective. Ed. by Lamour, K. Wallingford, UK: CABI, pp. 166-177.

Pérez-Sierra, A.; León, M.; Âlvarez, L. A.; Alaniz, S.; Berbegal, M.; García-Jiménez, J.; Abad-Campos, P., 2010: Outbreak of a new Phytophthora sp. associated with severe decline of almond trees in eastern Spain. Plant Dis. 94, 534-541.

Pérez-Sierra, A.; López-García, C.; León, M.; García-Jiménez, J.; Abad-Campos, P.; Jung, T., 2013: Previously unrecorded low temperature Phytophthora species associated with Quercus decline in a Mediterranean forest in Eastern Spain. Forest Pathol. 43, 331-339.

Queloz, V.; Grünig, C. R.; Berndt, R.; Kowalski, T.; Sieber, T. N.; Holdenrieder, O., 2011: Cryptic speciation in Hymenoscyphus albidus. Forest Pathol. 41, 133-142.

Rea, A.; Jung, T.; Burgess, T. I.; Stukely, M. J. C.; Hardy, G. E.; St, J., 2010: Phytophthora elongata sp. nov. a novel pathogen from the Eucalyptus marginata forest of Western Australia. Australas. Plant Path. 39, 477-491.

Rea, A. J.; Burgess, T. I.; Hardy, G. E.; St, J.; Stukely, M. J. C.; Jung, T., 2011: Two novel and potentially endemic species of Phytophthora associated with episodic dieback of kwongan vegetation in the south-west of Western Australia. Plant. Pathol. 60, 1055-1068.

Reeser, P. W.; Sutton, W.; Hansen, E. M.; Remigi, P.; Adams, G. C., 2011: Phytophthora species in forest streams in Oregon and Alaska. Mycologia 103, 22-35.

Rizzo, D. M.; Garbelotto, M.; Davidson, J. M.; Slaughter, G. W.; Koike, S. T., 2002: Phytophthora ramorum as the cause of extensive mortality of Quercus spp. and Lithocarpus densiflorus in California. Plant Dis. 86, 205-214.

Robin, C.; Desprez-Loustau, M. L.; Capron, G.; Delatour, C., 1998: First record of Phytophthora cinnamomi on cork and holm oaks in France and evidence of pathogenicity. Ann. For. Sci. 55, 869-883. 
Santini, A.; Ghelardini, L.; De Pace, C.; Desprez-Loustau, M. L.; Capretti, P.; Chandelier, A.; Cech, T.; Chira, D.; Diamandis, S.; Gaitniekis, T.; Hantula, J.; Holdenrieder, O.; Jankovsky, L.; Jung, T.; Jurc, D.; Kirisits, T.; Kunca, A.; Lygis, V.; Malecka, M.; Marcais, B.; Schmitz, S.; Schumacher, J.; Solheim, H.; Solla, A.; Szabò, I.; Tsopelas, P.; Vannini, A.; Vettraino, A. M.; Woodward, S.; Webber, J.; Stenlid, J., 2013: Biogeographic patterns and determinants of invasion by alien forest pathogens in Europe. New Phytol. 197, 238-250.

Scanu, B.; Hunter, G. C.; Linaldeddu, B. T.; Franceschini, A.; Maddau, L.; Jung, T.; Denman, S., 2014a: A taxonomic re-evaluation reveals that Phytophthora cinnamomi and P. cinnamomi var. parvispora are separate species. Forest Pathol. 44, 1-20.

Scanu, B.; Linaldeddu, B. T.; Peréz-Sierra, A.; Deidda, A.; Franceschini, A., 2014b: Phytophthora ilicis as a leaf and stem pathogen of Ilex aquifolium in Mediterranean islands. Phytopathol. Mediterr. 53, 480-490.

Schrader, G.; Unger, J.-G., 2003: Plant quarantine as a measure against invasive alien species: the framework of the International Plant Protection Convention and the plant health regulations in the European Union. Biol. Invasions 5, 357-364.

Schwingle, B. W.; Smith, J. A.; Blanchette, R. A., 2007: Phytophthora species associated with diseased woody ornamentals in Minnesota nurseries. Plant Dis. 91, 97-102.

Scibetta, S.; Schena, L.; Chimento, A.; Cacciola, S. A.; Cooke, D. E. L., 2012: A molecular method to assess Phytophthora diversity in environmental samples. J. Microbiol. Meth. 88, 356-368.

Scott, P. M.; Burgess, T. I.; Barber, P. A.; Shearer, B. L.; Stukely, M. J. C.; Hardy, G. E.; St, J.; Jung, T., 2009: Phytophthora multivora sp. nov., a new species recovered from declining Eucalyptus, Banksia, Agonis and other plant species in Western Australia. Persoonia 22, 1-13.

Shearer, B. L.; Tippett, J. T., 1989: Jarrah dieback: The dynamics and management of Phytophthora cinnamomi in the jarrah (Eucalyptus marginata) forests of south-western Australia. Perth: Department of Conservation and Land Management, $76 \mathrm{pp.}$

Streito, J. C.; Legrand, P.; Tabary, F.; Jarnouen de Villartay, G., 2002: Phytophthora disease of alder (Alnus glutinosa) in France: investigations between 1995 and 1999. Forest Pathol. 32, 179-191.

Testa, A.; Schilb, M.; Lehman, J. S.; Cristinzio, G.; Bonello, P., 2005: First report of Phytophthora insolita and P. inflata on Rhododendron in Ohio. Plant Dis. 89, 1128.

Themann, K.; Werres, S.; Lüttmann, R.; Diener, H.-A., 2002: Observations of Phytophthora spp. in water recirculation systems in commercial hardy ornamental nursery stock. Eur. J. Plant Pathol. 108, 337-343.

Tsao, P. H., 1990: Why many Phytophthora root rots and crown rots of tree and horticultural crops remain undetected. Bull. OEPP/EPPO Bull. 20, 11-17.

Vettraino, A. M.; Natili, G.; Anselmi, N.; Vannini, A., 2001: Recovery and pathogenicity of Phytophthora species associated with a resurgence of ink disease in Castanea sativa in Italy. Plant. Pathol. 50, 90-96.

Vettraino, A. M.; Barzanti, G. P.; Bianco, M. C.; Ragazzi, A.; Capretti, P.; Paoletti, E.; Luisi, N.; Anselmi, N.; Vannini, A., 2002: Occurrence of Phytophthora species in oak stands in Italy and their association with declining oak trees. Forest Pathol. 32, 19-28.

Vettraino, A. M.; Morel, O.; Perlerou, C.; Robin, C.; Diamandis, S.; Vannini, A., 2005: Occurrence and distribution of Phytophthora species associated with Ink Disease of chestnut in Europe. Eur. J. Plant Pathol. 111, 169-180.

Vettraino, A. M.; Brasier, C. M.; Brown, A. V.; Vannini, A., 2011: Phytophthora himalsilva sp. nov. an unusually phenotypically variable species from a remote forest in Nepal. Fungal Biol. 115, 275-287.

Warfield, C. Y.; Hwang, J.; Benson, D. M., 2008: Phytophthora blight and dieback in North Carolina nurseries during a 2003 survey. Plant Dis. 92, 474-481.

Webber, J. F.; Brasier, C. M., 2005: Global pathways for tree pathogens: the challenges of Phytophthora species as invasive threats. In: Proceedings of Crop Science and Technology Congress, 31 Oct-2 Nov 2005. Glasgow, UK; Alton, UK: BCPC pp. 741-748.

Werres, S.; Marwitz, R.; Man In't Veld, W. A.; De Cock, W. A. M.; Bonants, P. J. M.; De Weert Themann, K.; Ilieva, E.; Baayen, R. P., 2001: Phytophthora ramorum sp. nov., a new pathogen on Rhododendron and Viburnum. Mycol. Res. 105, 1155-1165.

Widmer, T., 2011: Effect of temperature on survival of Phytophthora kernoviae oospores, sporangia, and mycelium. N. Z. J. For. Sci. 41S, 15-23.

Wilcox, W. F.; Scott, P. H.; Hamm, P. B.; Kennedy, D. M.; Duncan, J. M.; Brasier, C. M.; Hansen, E. M., 1993: Identity of a Phytophthora species attacking raspberry in Europe and North America. Mycol. Res. 97, 817-831.

Yakabe, L. E.; Blomquist, C. L.; Thomas, S. L.; MacDonald, J. D., 2009: Identification and frequency of Phytophthora species associated with foliar diseases in California ornamental nurseries. Plant Dis. 93, 883-890.

Zeng, H.-C.; Ho, H.-H.; Zheng, F.-C., 2009: A survey of Phytophthora species on Hainan Island of South China. J. Phytopathol. 157, 33-39.

\section{Supporting Information}

Additional Supporting Information may be found in the online version of this article:

Table S1. Phytophthora - infestation of fields and container stands of forest nurseries, and forest, riparian, amenity and landscape plantings of four Alnus spp. in Austria, Bulgaria, Croatia, Czech Republic, Germany, Hungary, Poland, Portugal, Spain, Sweden and the United Kingdom.

Table S2. Phytophthora - infestation of nursery fields and container stands, and forest, amenity, and landscape plantings of Castanea sativa in France, Germany, Greece, Hungary, Italy, Poland, Portugal, Slovakia, Spain and the United Kingdom.

Table S3. Phytophthora - infestation of nursery fields and container stands, and forest, amenity and landscape plantings of Fagus spp. in Austria, France, Germany, Poland, Serbia, Slovakia, Spain, Sweden and the United Kingdom.

Table S4. Phytophthora - infestation of 121 nursery fields and container stands of 11 Quercus spp. in France, Germany, Italy, the Netherlands, Poland, Portugal, Serbia and Spain.

Table S5. Phytophthora - infestation of 232 nursery fields and container stands of 60 broadleaved tree and shrub species for forest and amenity plantings in Austria, Croatia, Finland, France, Germany, Greece, Hungary, Italy, the Netherlands, Norway, Poland, Portugal, Spain, Switzerland and the United Kingdom.

Table S6. Phytophthora - infestation of 482 fields and container stands of 45 conifer species in forest nurseries and advanced tree nurseries in Austria, Croatia, France, Germany, Hungary, Italy, Norway, Poland, Portugal, Spain, Sweden and the United Kingdom.

Table S7. Phytophthora - infestation of 308 horticultural nursery fields and container stands of 33 horticultural species in Croatia, Hungary, Italy, Norway, Poland, Spain, Sweden and the United Kingdom. 
Table S8. Phytophthora - infestation of nursery fields and container stands of 142 ornamental broadleaved tree, shrub and herbaceous taxa in Austria, Croatia, Finland, France, Germany, Greece, Hungary, Italy, the Netherlands, Norway, Poland, Spain, Sweden, Switzerland and the United Kingdom.

Table S9. Phytophthora - infestation of 113 forest, amenity and landscape plantings of 12 Quercus spp. in Germany, Italy, Luxembourg, Poland, Portugal, Serbia, Slovakia, Spain, Switzerland and the United Kingdom.

Table S10. Phytophthora - infestation of 365 forest, amenity, landscape and riparian plantings of 99 broadleaved tree and shrub species in Austria, Croatia, Finland, Germany, Greece, Hungary, Italy, the Netherlands, Poland, Portugal, Serbia, Slovakia, Spain, Sweden, Switzerland and the United Kingdom.

Table S11. Phytophthora - infestation of 342 forest, amenity and landscape plantings of 32 conifer species in Austria, Croatia, Germany, Italy, Norway, Poland, Portugal, Slovakia, Spain, Sweden and the United Kingdom.

Table S12. Phytophthora - infestation of 688 horticultural plantings of 59 horticultural crop and fruit tree species in Austria, Bulgaria, Croatia, Germany, Greece, Hungary, Italy, Slovakia, Spain, Sweden and the United Kingdom.

Table S13. Phytophthora - infestation of 755 ornamental plantings of 281 broadleaved tree, shrub and herbaceous species in Croatia, Germany, Hungary, Italy, Spain, Sweden, Switzerland and the United Kingdom. 